\title{
SARS-CoV-2, ACE2, and Hydroxychloroquine: Cardiovascular Complications, Therapeutics, and Clinical Readouts in the Current Settings
}

\author{
Rajkumar Singh Kalra ${ }^{1, *,+}$ (D) Dhanendra Tomar ${ }^{2, *,+}\left(\mathbb{D}\right.$, Avtar Singh Meena $^{3}$ and \\ Ramesh Kandimalla 4,5 (D) \\ 1 AIST-INDIA DAILAB, DBT-AIST International Center for Translational \& Environmental \\ Research (DAICENTER), National Institute of Advanced Industrial Science \& Technology (AIST), \\ Higashi 1-1-1, Tsukuba 305 8565, Japan \\ 2 Center for Translational Medicine, Lewis Katz School of Medicine, Temple University, \\ Philadelphia, PA 19140, USA \\ 3 CSIR-Centre for Cellular and Molecular Biology (CCMB), Habsiguda, Uppal Road, \\ Hyderabad 500 007, Telangana State, India; avtar.ccmb@yahoo.com \\ 4 Applied Biology, CSIR-Indian Institute of Chemical Technology (IICT), Uppal Road, Tarnaka, \\ Hyderabad 500007, Telangana State, India; ramesh.kandimalla@iict.res.in \\ 5 Department of Biochemistry, Kakatiya Medical College, Warangal 506007, Telangana State, India \\ * Correspondence: raj-singh@aist.go.jp (R.S.K.); dhtomar@temple.edu (D.T.) \\ + Equal contribution.
}

Received: 1 June 2020; Accepted: 5 July 2020; Published: 7 July 2020

\begin{abstract}
The rapidly evolving coronavirus disease 2019 (COVID-19, caused by severe acute respiratory syndrome coronavirus 2- SARS-CoV-2), has greatly burdened the global healthcare system and led it into crisis in several countries. Lack of targeted therapeutics led to the idea of repurposing broad-spectrum drugs for viral intervention. In vitro analyses of hydroxychloroquine (HCQ)'s anecdotal benefits prompted its widespread clinical repurposing globally. Reports of emerging cardiovascular complications due to its clinical prescription are revealing the crucial role of angiotensin-converting enzyme 2 (ACE2), which serves as a target receptor for SARS-CoV-2. In the present settings, a clear understanding of these targets, their functional aspects and physiological impact on cardiovascular function are critical. In an up-to-date format, we shed light on HCQ's anecdotal function in stalling SARS-CoV-2 replication and immunomodulatory activities. While starting with the crucial role of ACE2, we here discuss the impact of HCQ on systemic cardiovascular function, its associated risks, and the scope of HCQ-based regimes in current clinical settings. Citing the extent of HCQ efficacy, the key considerations and recommendations for the use of HCQ in clinics are further discussed. Taken together, this review provides crucial insights into the role of ACE2 in SARS-CoV-2-led cardiovascular activity, and concurrently assesses the efficacy of HCQ in contemporary clinical settings.
\end{abstract}

Keywords: SARS-CoV-2; COVID-19; ACE2; hydroxychloroquine; cardiovascular system; cardiovascular disease (CVD); therapeutics

\section{Introduction}

A new type of pneumonia outbreak surfaced in December 2019 in Wuhan, Hubei province, China, which was caused by a novel coronavirus, viz., severe acute respiratory syndrome coronavirus (SARS-CoV)-2 [1]. The pandemic disease, named coronavirus disease 2019 (COVID-19), had 5,867,727 confirmed cases by 29th May 2020 and resulted in 362,238 deaths globally, as sourced 
by the Coronavirus Resource Center, John Hopkins University (JHU) (https://coronavirus.jhu. edu/). SARS-CoV-2 shares $82 \%$ genomic similarity with the other SARS-CoVs, while two other bat-SARS-CoV-like viruses (retrieved from Rhinolophus sinicus, Zhoushan, China), viz., bat-SL-CoVZC45 and bat-SL-CoVZXC21 were found to have $>89 \%$ similarity [1]. To date, SARS-CoV-2 has crossed all continental boundaries, and presently Europe and North America have been its major epicenters. The COVID-19 symptoms are comparable to those produced by SARS-CoV and Middle East respiratory syndrome (MERS). However, the earliest estimate showed its lower (2\%) fatality rate, while about $\sim 20 \%$ of COVID-19 patients had developed severe conditions [2]. SARS-CoV-2 tropism to the lungs/respiratory system is prominent, in which it infects the lung cells and causes interstitial pneumonitis that may lead to developing acute respiratory distress syndrome (ARDS) and manifestations related to the cardiovascular (CV) system causing multiple organ failure [3-8]. Amongst severe COVID-19 patients, 23\% of cases had cardiac injuries [9] and, therefore, highlighted this as a common feature that promotes disease severity. Of note, elevated levels of creatinine kinase $(\mathrm{CK} ;>200 \mathrm{U} / \mathrm{L})$ in $13 \%$ of COVID-19 patients in the general cohort, where most of these lacked any cytokine storm-induced systemic inflammatory response, further affirmed the association of COVID-19 with cardiovascular complications [2]. The common CV complications reported in COVID-19 patients include arrhythmia, myocardial injury (marked by higher troponin I (hs-cTnI) and CK levels) and myocarditis, acute myocardial infarction, acute heart failure and cardiomyopathy, and disseminated intravascular coagulation (DIC) $[3,4,10,11]$. Although the association of SARS-CoV-2 infection with these manifestations is now known, preexisting CV comorbidities could further contribute to COVID-19 severity and mortality $[3,4,10,11]$. The earliest report describing a meta-analysis of the COVID-19 clinical cohort revealed a strikingly high existing prevalence of hypertension and cardiovascular disease (CVD) in hospitalized patients, that made them prone to require critical care [10]. COVID-19 patients with CVDs were found to have a relatively five-fold higher mortality risk as compared to the patients with no CVD background [4].

SARS-CoV-2 interacts with an ACE (Angiotensin-converting enzyme) homolog, viz., transmembrane angiotensin-converting enzyme 2 (ACE2) to enter border-line host cells including type II pneumocytes, perivascular pericytes, macrophages, and cardiac cardiomyocytes [12,13]. ACE2 is a carboxy-monopeptidase and an essential component of the renin-angiotensin system (RAS), where it critically participates in maintaining normal CV functions while its dysregulation, observed in multiple CVDs, includes hypertension, myocarditis, and heart failure [14]. Expression of ACE2 on pericytes and cardiomyocytes brought heart and CV tissues to potential risk for SARS-CoV-2 infection, and therefore explained a higher prevalence of CV complications in COVID-19 patients. With the evolving COVID-19 pandemic situation, tremendous pressure and a lack of targeted anti-viral or vaccine prompted researchers and clinicians to consider all available therapeutic options. In this context, the two aminoquinolines, viz., Chloroquine (CQ) and Hydroxychloroquine (HCQ, a less-toxic derivative of CQ) were repurposed widely as therapeutic options for COVID-19. In multiple reports earlier, CQ was shown to be effective in inhibiting SARS-CoV viral replication in vitro [15-17]. This evidence prompted an early assessment of CQ and HCQ efficacies against SARS-CoV-2 [18-20], where in post-SARS-CoV-2 infection HCQ was found to impair viral replication more effectively than CQ [18]. These preliminary in vitro findings pave the way to assess the therapeutic application of HCQ in clinical studies [21-25]. As of May 29, 2020, searching with "COVID" and "Hydroxychloroquine" terms, 206 clinical trials including that of the National Institutes of Health $(\mathrm{NIH})$ are in progress to assess the therapeutic utility of HCQ globally (details available at https://clinicaltrials.gov/ct2/home). HCQ's anecdotal repurposing is now being extensively exercised in clinics worldwide. However, in the light of SARS-CoV-2 infection, ACE2 function, and emerging CV challenges, we lacked a clear understanding of HCQ's pharmacology, mode of action, benefits, and inevitable risks for COVID-19 patients. In this review, we provide insights into the crucial part ACE2 plays in SARS-CoV-2 infection and its significance in systemic cardiovascular function and reviewed the impact of HCQ on SARS-CoV-2 replication and immunomodulatory activities. Taking readouts from clinical COVID-19 studies so far, we reviewed cardiovascular risk 
and the benefits of HCQ in current clinical settings. We further brief on key considerations in HCQ repurposing and its future perspectives.

\section{SARS-CoV-2, ACE2, and Cardiovascular Challenges}

SARS-CoV-2 is a non-segmented, single-stranded (ss), positive (+) sense RNA virus [26]. It belongs to the family of enveloped RNA beta-coronavirus. Out of seven known species of beta-coronavirus, only three (SARS, MERS, and COVID-19) cause potentially fatal human disease. SARS-CoV-2 produces a 50-200 nanometers virion that is constituted by four structural proteins, viz., the $\mathrm{S}$ (spike), E (envelope), $\mathrm{M}$ (membrane), and $\mathrm{N}$ (nucleocapsid), wherein the $\mathrm{N}$ protein is aligned with its RNA genome, while the S, M, and E proteins collectively constitute the viral envelope [27]. The S protein at the SARS-CoV-2 envelop resembles a spike projection that serves as a tool for it to enter the host cell [28]. Phylogenetic analysis revealed 99\% similarity of S protein comparing SARS-CoV-2 and SARS-CoV [29] and therefore reaffirmed the evidence that SARS-CoV-2 exploits the same ACE2 receptor [1] that originally served as a functional receptor for SARS-CoV [30].

ACE2 is present in alveolar epithelial cells and frequently localized at the cell membrane of enterocytes (intestine), pericytes, cardiomyocytes, and macrophages [12,13,31]. ACE2 at the surface of pericytes and cardiomyocytes serves a vital activity of the RAS by maintaining normal CV functions by catalyzing the Ang (angiotensin) I and II [14]. SARS-CoV-2's S protein primarily binds to the ACE2 of alveolar epithelial cells in the respiratory tissues that enable its further access to the systemic circulation, reaching cardiomyocytes in the heart and pericytes and endothelial cells in the macro-vessels (Figure 1A). Endocytosis-driven internalization of ACE2 on the membrane of cardiomyocytes, pericytes, and endothelial cells by SARS-CoV-2 results in omitting ACE2 from the cell surface and potentially raises the risk of CV complications in COVID-19 patients [32]. The loss of ACE2 carboxypeptidase function was earlier shown to compromise cardiac function [33]. A higher ACE2 level in patients with existing CVD and/or hypertension was also suggested to increase the susceptibility to SARS-CoV-2 infection [34]. In light of this information, clinical readouts from six studies, including 1527 COVID-19 patients, revealed $17.1 \%, 16.4 \%$, and $9.7 \%$ prevalence of hypertension, cardiac \& cerebrovascular disease, and diabetes, respectively [10]. Prevalence of these CVD comorbidities was found to be higher in patients requiring ICU than the non-ICU patient groups. Analyses of mortalities in a cohort of 44,672 COVID-19 patients from Wuhan, China also showed $10.5 \%, 7.3 \%$, and $6 \%$ mortalities in patients having CVD, diabetes, and hypertension, respectively, significantly greater than the overall mortality rate (2.3\%) for COVID-19 patients [4]. To date, nine clinical studies from China [2,4-8,35-37] have comprehensively assessed CV comorbidities in COVID-19 patient cohorts and yielded similar clinical results (Figure 1B). However, disparities in testing, standardization and options for standard procedure in clinical studies from China $[6,8,38,39][2,37,40]$ and elsewhere [40] have impacted the quantitative clinical outcomes. To assess the cardiovascular outcomes of SARS-CoV-2 infection in a recent report, Liu et al. reported a significantly higher level of circulating Ang II in COVID-19 patients than the controls; circulating Ang II in levels COVID-19 patients also correlated well with viral load [41]. Of note, these results were consistent with reduced ACE2 activity. They again underlined the crucial role of RAS in COVID-19 disease and reaffirmed the focus on the cardio-protective function of ACE2, where an alteration in its activity may substantially impact the cardiovascular outcomes [33,34]. Therefore, in light of these reports, ACE2 has gained recognition as a key and central target in COVID-19 pathology and associated CV complications. Taking note of SARS-CoV-2 infection severity, here we review the frequent clinical cardiovascular complications observed in COVID-19 patients and further shed light on the potential involvement of ACE2 activity. 


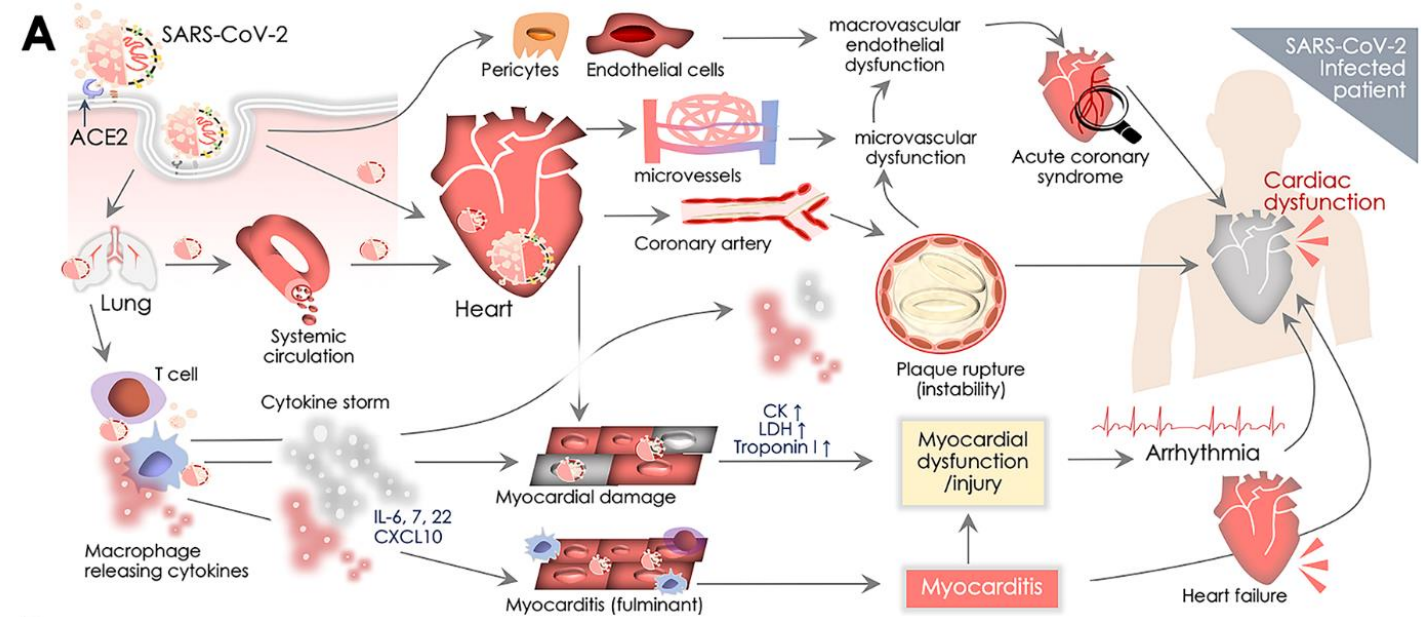

B
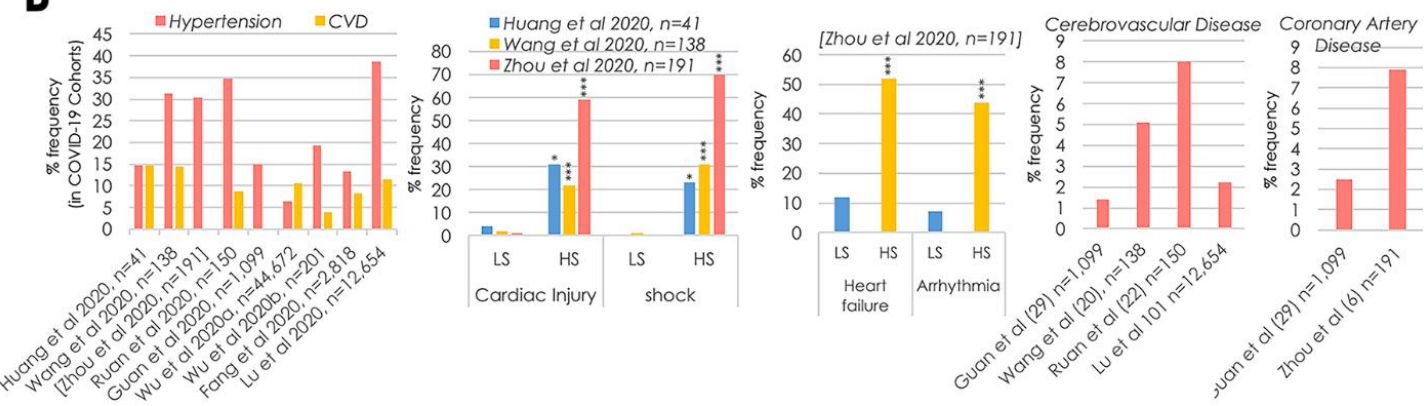

Figure 1. SARS-CoV-2, angiotensin converting enzyme 2 (ACE2), and cardiovascular complications. (A) Transmembrane ACE2 receptor facilitates SARS-CoV-2 entry to host cell primarily in the lungs, and then the vascular system, postulating cardiovascular complications by causing inflammation and myocardial dysfunction. SARS-CoV-2 access to the systemic circulation via the lungs potentiates heart infection, while its direct infection of associated pericytes and endothelial cells may cause vascular endothelial dysfunction. Cardiac SARS-CoV-2 infection causes micro-vessel dysfunction, and elevated immunoreactivity disrupts atherosclerotic plaques leading to the progression of the acute coronary syndromes. SARS-CoV-2 infection of alveolar pneumocytes (type II) cells progressively develops the systemic inflammation and elevated immunoreactivity that eventually produces the 'cytokine storm', marked by elevated IL-6, IL-7, IL-22, and CXCL10 cytokine levels. It potentiates T-cell and macrophage activation infiltrating infected myocardial tissues and may produce severe cardiac damage and myocarditis, leading to heart failure. Cytokine storm may further increase damage of cardiac monocytes causing myocardial dysfunction and subsequent development of arrhythmia. These events cumulatively produce cardiac dysfunction. (B) Manifestation (\%) of cardiovascular complications in hospitalized COVID-19 patients reported in key clinical studies exhibiting comorbidities including hypertension, cardiovascular disease (CVD), cerebrovascular disease, coronary artery disease and rate of cardiac injury, shock, heart failure, and arrhythmia in low (LS), and high severity (HS) patient groups. $p$ values indicate ${ }^{* * *}(<0.001),{ }^{* *}(<0.01)$, and $*(<0.05)$ statistical significance.

\subsection{Myocardial Injury, Shock, and Congestive Cardiac Failure}

An earlier diagnostic assessment of COVID-19 patients in Wuhan revealed an increase in the levels of cardiac cTnI (a myocardial injury marker $>28 \mathrm{pg} / \mathrm{mL}$ ) in five of the first 41 patients [6,34]. While recent analyses exhibited 7.2\% [8] to 17\% [7] incidences of acute myocardial injury in hospitalized COVID-19 patients, such risk was found to be six to twelve-fold higher in the high severity (HS) group than the low severity (LS) patient group (Figure 1B). Of note, multiple reports showed that elevated levels of lactate dehydrogenase (LDH) and serum creatine kinase (CK) were evident in almost all hospitalized COVID-19 patients [6,34,42]. Cases of other cardiac complications such as fulminant myocarditis were also evident and were suggested to be the outcome of SARS-CoV-2 infection (Figure 1A). A recent 
study reported $23 \%$ cases of congestive cardiac failure in COVID-19 patients among all in-hospital Chinese patients (Figure 1B). Markedly, these incidences in deceased and survivor cases were found to be $52 \%$ and $12 \%$, respectively [7]. A lack of information on the possible association of cTnl increase with pre-existing CV complications limits our ability to predict causalities. However, an increase in cTnl levels was found to depict poor prognosis in other systemic diseases. Therefore, such associations of cTnl levels with prognosis is likely to predict the risk of systemic diseases, e.g., hypotension or hypoxia, then a specific cardiac dysfunction. In the given context, the role of the 'cytokine storm' elicited by SARS-CoV-2 immunoreactivity appears to be a key mediator [34]. Aberrant expressions of a variety of cytokines are evident in severely ill COVID-19 patients, while elevated plasma interleukin-6 (IL-6) levels were seen in patients with cardiac injury [43] (Figure 1A). Given the fact that ACE2 levels are present at the cell surface and in circulation in the CV system, direct SARS-CoV-2's cardiomyocyte infection is suggested to be a definite possibility [44].

\subsection{Cardiac Arrhythmia}

Manifestations of viral infections are frequently seen to be associated with myocardial inflammation, metabolic dysfunction, and modulation of the sympathetic nervous system that all serve as key factors in causing the cardiac arrhythmia. A meta-analysis of 138 COVID-19 patients cohort reported 16.7\% incidences of developing arrhythmia in patients, which in terms of serious complications came second after ARDS [8]. Another cohort comparing patients based on their admittance to ICU revealed strikingly higher (44\%) cases of arrhythmia in ICU admitted patients, while in the non-ICU admitted patients group it remained at 4\% [39] (Figure 1B). These findings postulated the role of systemic inflammation and elevated immunoreactivity produced by cytokine storm that may damage cardiac monocytes causing myocardial dysfunction and subsequent development of arrhythmia (Figure 1A). The internalization of ACE2 by SARS-CoV-2 served as a key event that led to the altered RAS system, which was postulated earlier to cause pro-inflammatory and pro-oxidant activities [32].

\subsection{Myocarditis}

Acute viral infections are known to cause cardiac injury and acute myocarditis. A recent report by the National Health Commission, China, showed the infiltration of mononuclear cells and the onset of monocyte necrosis in cardiac muscle autopsy specimens. Along these lines, other findings concerning fulminant myocarditis indicate the possibility of myocarditis in COVID-19 patients as a cause of acute cardiac injury $[43,45]$. Despite the findings of these reports and individual clinical cases $[43,45]$, we presently lack any information on the underlying mechanism, its prevalence, and clinical importance, and therefore this emphasizes the need for detailed clinical analyses. However, the earliest reports suggested that fulminant myocarditis may potentially be a clinical manifestation of SARS-CoV-2 infections of cardiomyocytes [43,45], postulated to be caused by elevated IL-6, IL-7, IL-22, and CXCL10 cytokine levels produced as a result of cytokine storm (Figure 1A). ACE2-led SARS-CoV-2 infection of alveolar pneumocytes (type II) cells has been suggested to trigger the onset of systemic inflammation and elevated immunoreactivity leading to a 'cytokine storm', that may essentially potentiate T-cell and macrophage activation infiltrating infected myocardial tissues and resulting in cardiac damage and myocarditis (Figure 1A). However, a detailed assessment of these events is needed to further confirm the acquisition of systemic myocarditis in COVID-19 patients.

\subsection{Acute Coronary Disease (ACD) and Ischemia}

Most clinical studies so far lack any insights into ACD in COVID-19 patients; however, it is suggested that it impacts on destabilizing coronary plaques in COVID-19 patients [7,46,47]. Of note, the role of the systemic inflammatory response is implicated primarily in destabilizing atherosclerotic plaques [48], which further supports pro-inflammatory and pro-oxidative consequences of SARS-CoV-2-led ACE2 loss in COVID-19 patients (Figure 1A,B). More specifically, COVID-19 patients with heart failure are at higher risk of acute events or ischemic syndrome. 


\subsection{Disseminated Intravascular Coagulation (DIC)}

Incidences of pulmonary embolism (PE) and subsequent disseminated intravascular coagulation (DIC) are linked with coronavirus infection, as COVID-19 patients demonstrate a hypercoagulable state, marked by prolonged prothrombin time, elevated D-dimer level and fibrin split. Of note, $71.4 \%$ of non-survivor patients were found to have DIC [49]. COVID-19 patients characteristically also had vast pulmonary embolism features [50]. Importantly, increase in D-dimer in COVID-19 patients was suggested to predict adverse survival outcome, for instance, a study of a retrospective cohort showed that increased D-dimer levels ( $>1 \mathrm{~g} / \mathrm{L}$ ) were able to closely predict in-hospital mortality [7]. However, the mechanistic basis of these features of SARS-CoV-2 infection is yet to be elucidated, while new knowledge of pro-inflammatory/oxidant activities in these syndromes could further shed light on the underlying role of ACE2 function in SARS-CoV-2 pathogenesis.

\subsection{Immune Function in Cardiovascular Complications}

After respiratory infection, the immune response is the second most exploited system in COVID-19 patients, and this has severe implications for the cardiovascular system. Firstly, Huang et al. reported elevated systemic IL-2, IL-6, IL-7, C-X-C motif chemokine 10 (CXCL10), chemokine (C-C motif) ligand 2 (CCL2), tumor necrosis factor- $\alpha(\mathrm{TNF} \alpha)$, and granulocyte colony-stimulating factor (G-CSF) levels in COVID-19 patients [6]. The elevated levels of systemic cytokines shared clinical features with cytokine release syndrome (CRS) [13] that may substantially contribute to COVID-19 severity. The above systemic immune response resembles cytokine profiles raised in hemophagocytic lympho-histiocytosis (HLH) syndromes [51]. Sorting of the immune cell population in COVID-19 patients revealed the presence of hyperactivated T-cells with high fractions of HLA-DR+, CCR6+ Th17 CD4+ and CD38+ CD8+/CD4+ T-cells. This emphasized the role of hyperactivated T-cells, which may partly be associated with severe immune injury [13]. Furthermore, elevated levels of circulating IL-6 in a cohort of 150 patients in a recent retrospective study were found to be predictive of mortality in hospitalized COVID-19 patients [5]. Of note, the role of IL-6 has been earlier primarily implicated in CV complications, including atherosclerosis and coronary heart disease, and with increasing the risk of cardiac inflammation and morbidity $[52,53]$. Therefore, the prevalence of systemic cytokine response/CRS or cytokine storm in clinical COVID-19 patients significantly raises an obvious risk of cardiovascular complications (Figure 1A).

\section{ACE2 Receptor and Its Significance in Systemic Cardiovascular Function}

ACE2 comprises an 805-amino acid (aa; Mr 110,000 glycoprotein) long endothelium-bound carboxy-mono-peptidase that consists of a 17-aa N-terminal peptide (catalytic domain-oriented extracellularly) and a C-terminal anchor integrated into the membrane. ACE2 is catalytically a zinc metalloprotease and the only homolog of ACE known in humans [54]. ACE2 is part of the RAS that plays a crucial function in maintaining normal cardiovascular functions, while dysfunction in RAS contributes to CVDs, including hypertension, myocarditis, coronary heart disease, and heart failure [14]. RAS is constituted by a set of catalytic enzymes that includes angiotensinogen, renin, Ang II, Ang II receptors (AT1R and AT2R), and ACE [55]. Among these, ACE2 has a crucial role to play by catalyzing Ang II to Ang (1-7) or Ang I to Ang (1-9) [56]. ACE2 can access substrate/peptide in the circulation, and it is known for its circulatory presence and catalytic function in the blood and body fluid. Given its carboxy-monopeptidase activity, ACE2 primarily trims the $\mathrm{COOH}$-terminal phenylalanine residue from Ang II [57]. ACE2-led trimming of Ang II to Ang (1-7) is a significant event in the RAS, since the role of Ang II is critically implicated in producing hypertension by promoting vasoconstriction, fibrosis, $\mathrm{Na}+$ retention, and pro-inflammation and pro-oxidant activities. At the same time, elevated levels of Ang (1-7) peptide inhibits the Ang II/AT1R axis and induces anti-inflammatory, anti-oxidant, anti-fibrotic, and vasodilatory activities (Figure 2A) [56,58]. Therefore, ACE2 activity switches on the processing of Ang II in the classical RAS system and loss of ACE2 or its function 
could put the RAS system to an overall higher Ang II level [58]. These cardioprotective activities of ACE2 are regulated through the Ang I (1-9)/AT2R and Ang I (1-7)/MasR axes [55].On the contrary, ACE degrades Ang (1-7) and forms ANG II that results in promoting inflammation, fibrosis, and high blood pressure (Figure 2). The role of ACE2 was also implicated in the hydrolysis of apelin and des-arginine bradykinin (des-Arg1-BK) apelin peptides, wherein des-Arg1-BK was shown to have a pro-inflammatory function via stimulating the B1 receptor [59] (Figure 2). Besides its critical role in the CV system, ACE2 was earlier discovered to be a key binding receptor for SARS-CoV and NL63 (HCoVNL63) coronaviruses [30,60], while recently it was identified to be a SARS-CoV-2 receptor [61]. ACE2 is also shown to play a key role in acute respiratory/lung injury caused by influenza viruses viz., H1N1, H5N1, and H7N9 [62-64].
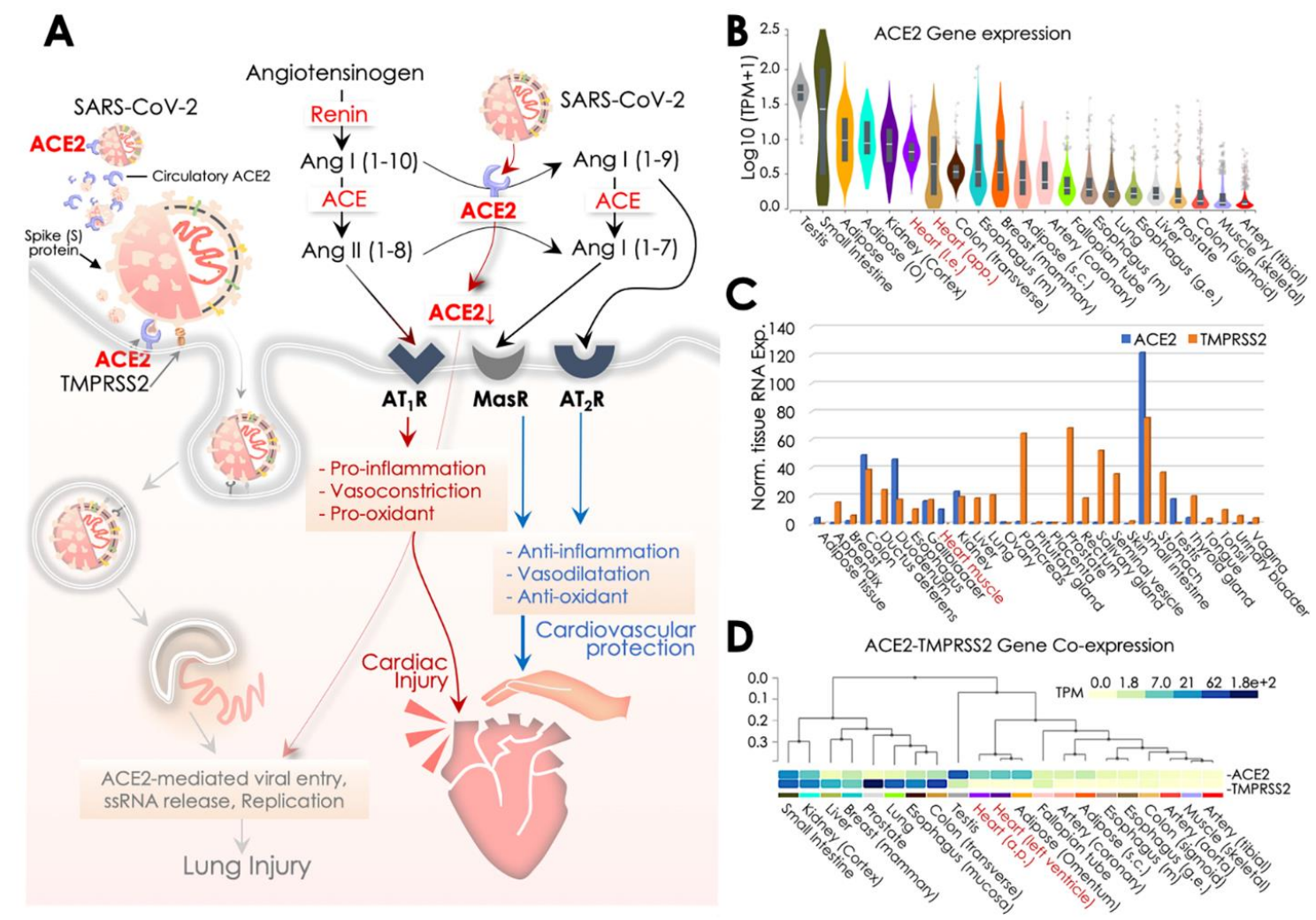

Figure 2. SARS-CoV-2 pathology and ACE2-led regulation of cardiovascular function of the Renin-Angiotensin System (RAS). (A) Schematic diagram illustrating the central role of ACE2 in SARS-CoV-2 recognition and the differential regulation of the RAS system for cardiovascular protection or cardiac injury. SARS-CoV-2 spike (S) protein undergoes priming by the TMPRSS2, a host cell membrane protease, and it subsequently binds to ACE2 infecting the host cell. In the RAS system, ACE2 activity with MasR, and AT2R receptors provides cardiovascular protection. In contrast, a reduced ACE2 activity as a result of its binding to SARS-CoV-2 and engulfment into the cell may elevate ACE activity and Ang II levels that essentially potentiates cardiac damage/injury. (B) ACE2 gene expression data of ACE2 retrieved from Genotype-Tissue Expression (GTEx) showing its expression across human tissues, wherein heart tissues are marked in red at x-axis. Expression values are shown in the $\log 10$ scale for TPM (Transcripts Per Million) unit. (C,D) ACE2 and TMPRSS2 mRNA levels retrieved from Human Protein Atlas (HPA; C) and Genotype-Tissue Expression (GTEx; D) showing their co-expression across various human tissues; heart tissues are marked in red at $\mathrm{x}$-axis.

Mechanistically, the intracellular entry of SARS-CoV-2 in host cells is facilitated by binding of its $S$ (spike) protein's receptor binding region with the ACE2 extracellular domain, at a high affinity (15 nM) [65]. Prior to their binding, the host cell serine protease, viz., TMPRSS2S, processes cleavage of S protein down the dibasic Arg sites and yields to the S1 and S2 subunits. S protein cleavage is a 
crucial step which enables S2-led membrane fusion and ACE2-mediated SARS-CoV-2 internalization by endocytosis $[66,67]$ in the type II pneumocytes, pericytes, or cardiomyocytes [12,13]. Structural analyses suggest that $S$ protein of SARS-CoV-2 has a receptor-binding domain (RBD) to interact with human ACE2, wherein 441Leu, 472Phe, 479Gln, 480Ser, 487Asn, and 491Tyr residues of S protein were predicted to have a critical role in its binding [68]. Higher virulence of SARS-CoV-2 than SARS-CoV was shown to reflect a higher affinity of S1 protein for ACE2 [69]. SARS-CoV-2 binding of ACE2 at the membrane and its subsequent loss by endocytosis impact RAS and change the overall Ang II:Ang (1-7) ratio (enriching cardio-inflammatory Ang II, and decreasing cardio-protective Ang (1-7) levels), eventually exacerbating cardiac injury by SARS-CoV-2. However, the extent of CV tissue damage due to the presence of SARS-CoV-2 in the circulation has not been precisely analyzed as yet [6,70]. ACE2 is a primary established route of Ang II metabolism that generates Ang (1-7) in the heart, and therefore its loss is frequently seen as compromising systemic cardiovascular function [32,71-73], wherein hypertension, inflammation, vasoconstriction, and oxidative activities have been the common CV complications $[32,60,74,75]$.

Given the fact that ACE2 circulating levels are endogenously deficient, its adequacy in preventing viral dissemination by sequestering SARS-CoV-2 in circulation was questioned [54], yet its protective effects against hypertension, myocardial hypertrophy, inflammation, and fibrosis were evident [76]. Also, amid these speculations [54,77], a proposed clinical trial (NCT04287686) to study the infusion of recombinant ACE2 to restrict viral infection was subsequently withdrawn. However, a recent report testing the potential of clinical-grade human recombinant soluble ACE2 (hrsACE2) in engineered human tissues showed an effective SARS-CoV-2 inhibition by a factor of 1000-5000. Therefore, soluble ACE2 might be the key therapeutic alternative restricting SARS-CoV-2 infection at early stage [78]. An alternative strategy using ACE2-specific antibodies to target membrane-aligned and soluble ACE2 was earlier found to be effective against SARS-CoV infection [79]. ACE2, inhibition of TMPRSS2 in the murine models also limited coronavirus infection and improved survival [80,81]. Presently, two ongoing clinical trials (NCT04321096 \& NCT04338906) are testing the efficacy of TMPRSS2 inhibition by camostat mesilate to evaluate its benefits against COVID-19.

TMPRSS2 is critical in the host recognition of SARS-CoV-2, and therefore for the $S$ protein it serves as a cofactor for ACE2-mediated viral entry into the host cell [12]. Hence, TMPRSS2 and ACE2 co-expression is crucial to facilitate an optimum SARS-CoV-2 infection. To get an insight into the above possibility, we firstly surveyed the ACE2 transcript expression at Genotype-Tissue Expression (GTEx) that revealed its enriched expression, particularly in testis, small intestine, adipose and heart/cardiac tissues (Figure 2B). This primarily explains the vulnerability of these tissues to SARS-CoV-2 infection. Of note, ACE2 transcript levels in the heart were higher than in the lungs which could help to explain the higher vulnerability of SARS-CoV-2 infection in the CV system and the prevalence of CV complications in COVID-19 patients. Similar observations were obtained in a recent report [44]. However, our survey of ACE2 and TMPRSS2 transcript co-expression at Human Protein Atlas (HPA; http://www.proteinatlas.org) further revealed a lesser co-occurrence of their expressions in the heart, while a strong correlation of their co-expression was observed in intestinal (colon, duodenum, small intestine) and renal tissues [82] (Figure 2C). Of note, a moderate expression of ACE2 and its co-expression with TMPRSS2 in the kidney/renal tissues also underlines association of SARS-CoV-2 infection with renal injury, which is frequently seen in COVID-19 patients. In critically ill patients admitted to ICU, 0.5-29\% incidences of acute kidney injury have been reported [2,6-9,38], and, thus, kidney injury was also recognized as a key feature of disease severity and correlated negatively for patient survival [7]. Interestingly, enzymatically active/secretory tissues (pancreas, prostate, salivary gland, seminal vesicle, stomach, and thyroid) were more enriched with TMPRSS2 expression. A much similar co-expression pattern of ACE2 and TMPRSS2 transcript was observed in the GTEx database (Figure 2D). Of note, in both analyses, a higher expression of TMPRSS2 was more evident in the lungs than the heart. However, the functional significance of such disparity in its expression warrants further investigation. Results of these surveys overlapped in parts with findings 
of an earlier report that analyzed co-expression of ACE2 and TMPRSS2, along with HAT in influenza and SARS-coronavirus, and reported their evident co-expression in respiratory, gastro-intestinal and cardiovascular tissues [83]. This evidence postulates that ACE2 and concomitant TMPRSS2 expression in pericytes and cardiomyocytes could essentially potentiate chances of SARS-CoV-2 infection in the systemic CV system and also explain the higher prevalence of CV issues in COVID-19 patients.

\section{SARS-CoV-2, ACE2, Hydroxychloroquine and beyond: Preventive and Therapeutic Aspects}

The ongoing COVID-19 pandemic prompted the urgent need to develop targeted therapeutic strategies and exercise all options of repurposing conventional drugs as a viable solution, considering their known pharmacological aspects and benefits. Efforts identified CQ and HCQ as two therapeutic drugs potentially useful in preventing COVID-19. The earliest reports analyzing the effects of CQ and HCQ in vitro against SARS-CoV-2 revealed their inhibitory antiviral activities $[19,84,85]$. Besides their earlier known antimalarial activity [86], these aminoquinoline analogs provide broad-spectrum benefits against types of bacterial, fungal, and viral infections [87-89]. Given its inexpensive cost, less toxicity, good tolerance, and immunomodulatory activities in patients [90], early reports in the last decade explored the repurposing of CQ against human immunodeficiency virus (HIV) and other viruses causing inflammation [91]. Therapeutic benefits of CQ's anti-inflammation and immunomodulatory activities were also explored in autoimmune diseases [92].

Keyaerts et al. in 2004, first demonstrated the antiviral activity of CQ against SARS coronavirus [16], while further reports revealed an inhibitory function of CQ on HCoV- 229E replication in epithelial lung cell in vitro $[93,94]$. Keyaerts et al. in 2009 also showed that infection of HCoV-O43 coronavirus in newborn mice could be treated by medication of CQ through the mother's milk [95]. With growing concerns about the toxicity of CQ medication in humans, HCQ, a less toxic derivative of CQ quinine analog, was subsequently opted for and used in clinical studies broadly. While keeping SARS-CoV-2 and ACE2 in focus, in the following sections we discuss the pharmacology of HCQ, its benefits in vitro and clinical settings, and what impact HCQ has upon SARS-CoV-2 replication and underlying immunomodulatory activities.

\subsection{HCQ Pharmacology, In Vitro and Clinical Outcomes}

The HCQ parental molecule, i.e., quinine, was first extracted from the Cinchona, a native tree to Peru, and primarily used for its benefits against malaria [96]. Later, an amine acidotrophic form of quinine, viz., CQ, was synthesized in Germany in 1934 as a natural substitute. CQ and its 4-aminoquinoline derivative, viz., HCQ, are both weak bases and share a common molecular family. Addition of a hydroxyl group at the CQ side-chain terminal end ( $\beta$-hydroxylation of the N-ethyl substituent) forms HCQ. It is usually administered orally in the form of HCQ sulfate, while its pharmacokinetics are similar to those of $C Q$, which include its swift absorption in the gastro-intestine and its renal release. HCQ, being a positively charged base, stays in a protonated form. However, un-protonated HCQ can access the intracellular organelles/compartments, where it becomes protonated, which, in turn, increases the localized $\mathrm{pH}$. This mechanism explains the accumulation of CQ/HCQ within acidic organelles, e.g., endosome, lysosomes, and the Golgi vesicles [97], and thus becomes one aspect of its pharmacokinetic activity. This fact may also explain its 200-700-times higher accumulation in splenic, hepatic, renal, and heart and lung than in plasma [98]. With its quick absorption, HCQ achieves its maximum concentration in serum in 2-3.5 h, while the half-life of its clearance was $22-45$ days [99].

Multiple in vitro studies performed earlier on SARS-CoV, exhibiting the benefits of CQ or HCQ against viral replication, provided an early hope for the potential repurposing of CQ/HCQ against COVID-19. Firstly, Keyaerts et al. in 2004 demonstrated that sub-toxic CQ concentration $(8.8+/-1.2 \mu \mathrm{M}$, much lower than the CC50 $(261.3+/-14.5 \mu \mathrm{M}))$ could effectively reduce the SARS-CoV replication rate in Vero E6 (kidney epithelial; source-African green monkey) cells by $50 \%$ [16]. In another report, Vincent et al. showed that, at $10 \mu \mathrm{M}, \mathrm{CQ}$ concentration effectively inhibited SARS-CoV viral replication in Vero 
E6 [15]. These inhibitory effects of CQ treatment were effective in pre- or post-SARS-CoV infected cells and therefore hinted at its prophylactic and therapeutic applications [15]. Biot et al. also observed a similar finding with CQ and HCQ; however, they reported that CQ causes more potent inhibition of viral replication [17]. These reports pitched the anecdotal benefits of $\mathrm{CQ} / \mathrm{HCQ}$ for their repurposing against the ongoing COVID-19 pandemic and prompted researchers to evaluate their activity against SARS-CoV-2. In the earliest efforts, Yao et al. analyzed the antiviral activities of HCQ and CQ on SARS-CoV-2 in Vero cell lines [18]. HCQ and CQ both showed SARS-CoV-2 inhibitory activity; however, in contrast to the study by Biot et al., which show better efficacy of CQ against SARS-CoV [17], Yao et al. showed that HCQ $(\mathrm{EC} 50=0.72 \mu \mathrm{M})$ has much higher antiviral potency than CQ $(\mathrm{EC50}=$ $5.47 \mu \mathrm{M}$ ) for SARS-CoV-2 [18]. In a post-infection treatment regime, HC impaired viral replication more effectively. While analyses of prophylactic activity also indicated the greater efficacy of HCQ (EC50-5.85Mm) than CQ (EC50-18.01Mm) in $48 \mathrm{~h}$, an extended treatment suggested the production of a more significant anti-viral effect [18]. To determine a potential clinical regime for HCQ, Yao et al. enrolled physiology-based pharmacokinetic modeling and considered multiple parameters, including drug administration route, its physiological assimilation (i.e., intestinal absorption and accessibility to lung tissue), and biochemical activities. This report also discussed simulated concentrations of lung fluid but lacked inclusion of all details used in the model [18]. Based on physiology-based pharmacokinetic modeling, Yao et al. proposed a treatment regime that included an initial dose of $400 \mathrm{mg}$ HCQ twice a day and a continuation of $200 \mathrm{mg}$ dose twice daily for the next four days, which turned out to be a key outcome of this study. However, the study lacked a $95 \%$ confidence interval value for the estimated EC50 dose, which suggests that the aforementioned dose regime needs to be adopted with caution to avoid inaccuracy in treatments [18]. Another report by Liu et al., using a similar antiviral regime at four multiplicities of infection, revealed the efficacy of CQ and HCQ in inhibiting SARS-CoV-2 viral replication at all four tested infection regimes [85]. Although they suggested a more robust potency of CQ than HCQ, this was only found to be significant at 0.01 and 0.2 multiplicities of infection. Importantly, using immunofluorescence-based co-localization assay, they analyzed entry of SARS-CoV-2 virion into the endosome-lysosome proteolysis pathway and found an accumulation of more virions at early endosomes and lesser at endolysosomes in CQ and HCQ treated cells in comparison to untreated viral infected control cells [85]. Using a similar Vero E6 cell system, Wang et al. further showed that a combination of remdesivir $(E C 50=0.77 \mu \mathrm{M})$ and $C Q$ $(\mathrm{EC} 50=1.13 \mu \mathrm{M})$ could effectively control viral infection in vitro [19]. This study enrolled SARS-CoV-2 at a multiplicity of infection (MOI) of 0.05 and pre-treated Vero E6 cells with $0.01,0.05,0.1,0.5,1,5$, and $10 \mu \mathrm{M}$ CQ for $1 \mathrm{~h}$. Regarding the antiviral activities of remdesivir and CQ, Wang et al. suggested their inclusion in clinical therapeutic regimes against SARS-CoV-2 [19]. In another combinatorial approach, Andreani et al. showed a synergistic effect of CQ and Azithromycin (AZM) against SARS-CoV-2 [100]. Using concentrations of 1,2 or $5 \mu \mathrm{M} C Q$ along with 5 or $10 \mu \mathrm{M}$ AZM and multiplicity of infection (MOI) at 0.25 they showed that $5 \mu \mathrm{M} C Q$ treatment in combination with 10 and $5 \mu \mathrm{M}$ AZ led relatively to $97.5 \%$ and $99.1 \%$ viral inhibition respectively [100]. The details of these in vitro studies testing efficacies of CQ and HCQ against SARS-CoV-2 are provided in Table 1, where the 2004 report of Keyaerts et al. is taken as reference.

Initial findings of HCQ/CQ antiviral activity from in vitro studies $[18,19,85,100]$ raised an early clinical interest in testing the efficacy of HCQ/CQ in the clinic for COVID-19 treatment. An interim analysis from China, including more than 100 COVID-19 patients, showed the superiority of CQ treatment compared to the control group [24]. Although this report provided no details of enrolled patients, their clinical features including the benefits of HQ in improving lung imaging, viral shedding, and in shortening disease course were discussed. One key takeaway from this study was the recommended CQ dose (500 $\mathrm{mg}$ twice daily -b.i.d.) for the next ten days for patients exhibiting mild, moderate or severe symptoms [24]. 
Table 1. Pre-clinical readouts from the key in vitro studies investigating therapeutic efficacy of HCQ against SARS-CoV-2. HCQ, Hydroxychloroquine; EC50, Effective concentration; AZM, Azithromycin.

\begin{tabular}{|c|c|c|c|c|}
\hline Investigation/References & Cell Systems & Drug, Concentration, and Assay Time (h) & Study Control & Key Findings/Comments \\
\hline Yao et al. 2020 & $\begin{array}{l}\text { Vero E6 cell (Origin-African } \\
\text { green Monkey) }\end{array}$ & $\begin{array}{l}\text { CQ and HCQ } \\
0.032,0.16,0.80,4,20, \& 100 \mu \mathrm{M} \\
2 \mathrm{~h}\end{array}$ & - & $\begin{array}{l}\text {-HCQ showed better SARS-CoV-2 inhibitory } \\
\text { activity than CQ. } \\
\text {-An extended incubation period may produce } \\
\text { greater anti-viral effect }\end{array}$ \\
\hline Liu et al. 2020 & Vero E6 Cells & $\begin{array}{l}\mathrm{CQ} \text { and HCQ } \\
0.068,0.21,0.62,1.85,5.56,16.67 \text {, and } 50 \mu \mathrm{M} \\
1 \mathrm{~h}\end{array}$ & PBS (Phosphate buffer saline) & $\begin{array}{l}\text {-HCQ inhibited the steps including infection/entry } \\
\text { and post-infection } \\
\text {-At the higher viral replication rate, anti-viral } \\
\text { efficacy of HCQ found to be lesser than of CQ }\end{array}$ \\
\hline Wang et al. 2020 & Vero E6 Cells & $\begin{array}{l}\mathrm{CQ} \text { and others * } \\
0.01,0.05,0.1,0.5,1,5 \text {, and } 10 \mu \mathrm{M} \\
1 \mathrm{~h}\end{array}$ & DMSO & $\begin{array}{l}\text { - } \mathrm{HCQ} \text { inhibited the viral activity at low } \mu \mathrm{M} \text { conc. } \\
\text { (effective conc. EC50 }=1.13 \mu \mathrm{M} \text { ) } \\
\text {-CQ effectively inhibited SARS-CoV-2 infection } \\
\text { in vitro }\end{array}$ \\
\hline Andreani et al. 2020 & Vero E6 cells & $\begin{array}{l}\mathrm{CQ}-1,2 \text { or } 5 \mu \mathrm{M} \text { associated with } 5 \text { or } 10 \mu \mathrm{M} \text { for } \\
\text { azithromycin. }\end{array}$ & - & $\begin{array}{l}\text { Combination of hydroxychloroquine and } \\
\text { azithromycin has a synergistic effect in vitro on } \\
\text { SARS-CoV-2 at concentrations }\end{array}$ \\
\hline $\begin{array}{l}\text { Keyaerts et al. } 2004\left({ }^{*} \text { Earliest }\right. \\
\text { report from the SARS-CoV) }\end{array}$ & Vero E6 cell & $\begin{array}{l}\text { CQ } \\
0,0.8,4,20, \& 100 \mu \mathrm{M} \\
8 \mathrm{~h} \text { to } 3 \text { days }\end{array}$ & - & $\begin{array}{l}\text {-CQ potently inhibits SARS-CoV activity at a lesser } \\
(8.8 \pm 1.2 \mu \mathrm{M}) \text { concentration than its cytostatic } \\
\text { activity }(261.3 \pm 14.5 \mu \mathrm{M}) \\
\text {-Addition of CQ even after } 5 \mathrm{~h} \text { of SARS-CoV } \\
\text { infection could yet be inhibitory active }\end{array}$ \\
\hline
\end{tabular}


A comprehensive review of available clinical data so far on the prophylactic and therapeutic use of HCQ/CQ against COVID-19 in human cohorts included nine clinical studies and two case series/reports, as summarized in the Table 2. In the earliest report, Chen et al. analyzed the efficacy of HCQ in a small-size (30 inpatients) randomized controlled trial in Shanghai, China [21]. When comparing the clinical outcome of HCQ to the standard of care, they found no statistically significant differences in virus clearance in control $(93 \%, p>0.05)$ and HCQ $(87 \%)$ group by day 7 . Also, no difference in the clinical symptoms, including the fever, its duration, and any alteration in lung features was observed in $400 \mathrm{mg}$ HCQ treated patients for five days. Although the admitted patients in control and HCQ groups had symptoms for $\sim 6$ and 7 days respectively, no detail of COVID-19 severity in the enrolled patients was reported. In mid-March 2020, Gautret et al., in an open-label, non-randomized clinical trial, reported that HCQ causes significant viral clearance at day 6 from the nasopharynx of treated patients $(60 \%)$ as compared to control (15\%) [22]. A faster viral clearance in patients who were given HCQ and Azithromycin (AZM) was reported and hinted at the synergistic effect of the two drugs. Given its non-randomized, unequal settings, and exclusion of six patients from analyses [22], the clinical outcome of this study was criticized. Another report from this group with a non-randomized cohort of 80 patients (with $\sim 5$ days symptoms) treated with HCQ and AZM revealed that $93 \%$ treated patients were negative of SARS-CoV-2 in just 4.5 days of treatment, as validated using reverse transcription-polymerase chain reaction (RT-PCR) of nasopharynx samples [25]. An absence of a comparison arm in this analysis compromised the clinical outcome of the report. Malina et al., another group from France, testing the combination of HCQ and AZM in a prospective, open-label study showed that, out of ten patients, only two exhibited viral load reduction by day six, and they therefore doubted the clinical outcome of studies published by Gautret et al. [22]. In another report from China, Chen et al. using HCQ for a mild symptomatic COVID-19 patient cohort showed faster clearance of cough and fever in HCQ treated patients than control [101]. However, this report had several limitations, including the exclusion of patients for unclear reasons, delivery of antivirals, steroids, and intravenous immunoglobulin as standard therapy and no endpoint details (no information on mortality, viral clearance, and patient discharge). A preprint study from France, comprising retrospective/non-randomized trials of 181 inpatients, examined the efficacy of HCQ $(600 \mathrm{mg} /$ day $)$ in 84 patients, while 97 patients were taken as control [102]. Authors found no apparent benefits of HCQ compared to control, and $\sim 10 \%$ of patients given HCQ were discontinued due to change in their ECG reading. In a recent multi-centric, randomized controlled trial from China, Tang et al., enrolling 75 patients each in HCQ and control (receiving standard of care) groups, showed no significant difference in viral clearance in HCQ $(85.4 \%)$ and control $(81.3 \%, p=0.341)$ by day 28 [103]. Testing a $1200 \mathrm{mg}$ HCQ dose for the first three days followed by $800 \mathrm{mg}$ daily dose for the next two-three weeks, this post hoc trial did not support HCQ use for COVID-19 treatment. Recently, in one of the biggest open-label and non-randomized trial studies (comprising 1061 patients) testing HCQ and AZM combination in France, Million et al. showed, in a ten-day regime, good clinical outcome and viral cure observed in 973 HCQ+AZM treated patients (91.7\%) [104]. They recommend that prophylactic use of HCQ+AZ is safe and acquires a low fatality rate in patients. In contrast, in a preprint recent retrospective/non-randomized trial of veterans hospitalized in USA that were given HCQ and HCQ+AZM for groups of 97 and 113 patients respectively, Magagnoli et al. showed no evidence that HCQ, either with or without AZM, benefits patients and lessens the risk of mechanical support in treatment [105]. 
Table 2. Characteristics of HCQ therapeutic regimes and their outcomes in key comprehensive clinical studies.

\begin{tabular}{|c|c|c|c|c|c|c|c|c|c|}
\hline \multirow{2}{*}{ Investigation/Reference } & \multirow{2}{*}{$\begin{array}{l}\text { Investigation } \\
\text { Type/Design }\end{array}$} & \multicolumn{2}{|c|}{ Patients (Total No) } & \multirow{2}{*}{ Regimes } & \multirow{2}{*}{$\begin{array}{c}\text { Severity of } \\
\text { CovID-19 Disease }\end{array}$} & \multirow{2}{*}{ Results/Key Findings } & \multirow{2}{*}{ Comment } & \multirow{2}{*}{ Location } & \multirow{2}{*}{ Limitation } \\
\hline & & Con & HCQ & & & & & & \\
\hline Chen J et al. (2020) & $\begin{array}{l}\text { Randomized and } \\
\text { controlled trial }\end{array}$ & 15 & 15 & $\begin{array}{l}\text { HCQ- } 400 \mathrm{mg} \text { for } \\
5 \text { days }\end{array}$ & $\begin{array}{c}\text { 6-7 days } \\
\text { symptomatic } \\
\text { patients, unclear } \\
\text { severity }\end{array}$ & $\begin{array}{l}\text { Indifferent outcomes in } \\
\text { groups. By day } 7, \text { no } \\
\text { significant change in } \\
\text { conversion rate }(86.7 \% \\
\text { vs } 93.3 \%) \text { observed. }\end{array}$ & $\begin{array}{l}\text { Patients were tested } \\
\text { negative for } \\
\text { COVID-19 at } 2 \\
\text { weeks }\end{array}$ & $\begin{array}{l}\text { Shanghai, } \\
\text { China }\end{array}$ & $\begin{array}{l}\text { Smaller sample size. } \\
\text { Not peer-reviewed, } \\
\text { availability in } \\
\text { Chinese language }\end{array}$ \\
\hline Gautret P et al. (2020a) & $\begin{array}{l}\text { Open-label trail, } \\
\text { Non-randomized, } \\
\text { Non-blinded }\end{array}$ & 16 & 26 & $\begin{array}{l}\text { HCQ- } 600 \mathrm{mg} \text { for } \\
10 \text { days }\end{array}$ & $\begin{array}{c}\text { Asymptomatic } \\
\text { patients-17\%, } \\
\text { Patients with } \\
\text { respiratory } \\
\text { symptoms- } 61 \% \text {, } \\
\text { Chest CT } \\
\text { pneumonia +ve } \\
\text { patients- } 22 \% \\
\end{array}$ & $\begin{array}{c}\text { Unadjusted results } \\
\text { showed significantly } \\
\text { reduced viral titer at } \\
\text { day 6 (HCQ-70\% vs. } \\
\text { con 12.5\%, PCR based, } \\
p<0.01 \text { ) }\end{array}$ & $\begin{array}{l}\text { Exclusion of } 6 \\
\text { patients from data } \\
\text { (1- died, 1- } \\
\text { withdrew, 3 needed } \\
\text { ICU admission, 1- } \\
\text { lost follow-up) }\end{array}$ & $\begin{array}{l}\text { Marseille, } \\
\text { France }\end{array}$ & $\begin{array}{c}\text { Study design, } \\
\text { Smaller sample-size, } \\
\text { Exclusion of } 6 \\
\text { patients, } \\
\text { inconclusive } \\
\text { long-term outcomes }\end{array}$ \\
\hline Molina JM et al. (2020) & $\begin{array}{l}\text { Prospective } \\
\text { open-label } \\
\text { investigation }\end{array}$ & 0 & 10 & $\begin{array}{c}\text { HCQ- } 600 \mathrm{mg} \text { for } \\
5 \text { days + AZM } 500 \\
\mathrm{mg} \times 1 \text {, then } 250 \\
\mathrm{mg}\end{array}$ & $\begin{array}{l}10 \text { patients out of } 11 \\
\text { were on } \\
\text { supplemental } \\
\text { oxygen }\end{array}$ & $\begin{array}{l}8 \text { patients out of } 10 \\
\text { were positive at day 5-6 } \\
\text { (nasopharyngeal swab) } \\
\text { (80\%, } 95 \% \text { CI: } 49-94 \text { ) }\end{array}$ & $\begin{array}{c}\text { Patient died-1, } \\
\text { Patient transferred } \\
\text { to ICU-2, Patient } \\
\text { had no further HCQ } \\
\text { post prolongation } \\
\text { of QTc-1 } \\
\end{array}$ & Paris, France & $\begin{array}{l}\text { Smaller sample size. } \\
\text { Not peer-reviewed. }\end{array}$ \\
\hline Chen $Z$ et al. (2020) & $\begin{array}{l}\text { Parallel-group } \\
\text { trail Randomized }\end{array}$ & 31 & 31 & $\begin{array}{l}\text { HCQ- } 400 \mathrm{mg} \text { for } \\
5 \text { days }\end{array}$ & $\begin{array}{l}\text { Mild illness was } \\
\text { observed in CT } \\
\text { confirmed } \\
\text { pneumonia cases }\end{array}$ & $\begin{array}{l}\text { - Clinical recovery and } \\
\text { cough remission time } \\
\text { reduced in HCQ group, } \\
\text { while resolution of } \\
\text { pneumonia was higher } \\
(80.60 \% \text { vs. } 54.8 \%) \text { in } \\
\text { the HCQ group. }\end{array}$ & $\begin{array}{l}\text { Undefined status, } 4 \\
\text { patients developed } \\
\text { severe illness in the } \\
\text { control group }\end{array}$ & Wuhan, China & $\begin{array}{l}\text { Smaller sample size. } \\
\text { Not peer-reviewed. }\end{array}$ \\
\hline Gautret P et al. (2020b) & $\begin{array}{l}\text { Open-label trail, } \\
\text { Non-randomized, } \\
\text { Non-blinded }\end{array}$ & 0 & 80 & $\begin{array}{c}\text { HCQ- } 600 \mathrm{mg} \text { for } \\
10 \text { days }+500 \mathrm{mg}, \\
\text { followed by } 250 \\
\text { mg AZM }\end{array}$ & $\begin{array}{c}\text { Asymptomatic- } 5 \% \text {, } \\
\text { Pneumonia cases- } \\
54 \% \text {, Patients with } \\
\text { low national early } \\
\text { warning score } \\
\text { (NEWS) and mild } \\
\text { disease- } 92 \%\end{array}$ & $\begin{array}{c}\text { Decreased } \\
\text { nasopharyngeal viral } \\
\text { load at } 7 \text { th }(83 \% \\
\text { negative) and } 8 \text { th }(93 \%) \\
\text { days }\end{array}$ & $\begin{array}{l}\text { Patients discharged } \\
\text { from hospital - 65 } \\
(81.3 \%), \text { Patients } \\
\text { needed ICU } \\
\text { admission- } 1 \\
\text { Deceased- } 1\end{array}$ & $\begin{array}{l}\text { Marseille, } \\
\text { France }\end{array}$ & $\begin{array}{l}\text { Design of the study, } \\
\text { Smaller sample size. } \\
\text { Not peer-reviewed. } \\
\text { Short follow-up } \\
\text { time period }\end{array}$ \\
\hline Tang W et al. (2020) & $\begin{array}{l}\text { Open-label, } \\
\text { Multi-centric, } \\
\text { Randomized, } \\
\text { Controlled trial }\end{array}$ & 75 & 75 & $\begin{array}{l}\text { HCQ- } 200 \mathrm{mg} \text { for } \\
\text { first } 3 \text { days, } 800 \\
\text { mg for remaining } \\
\text { days (total 2-3 } \\
\text { weeks) }\end{array}$ & $\begin{array}{c}\text { Patients with } \\
\text { mild-moderate } \\
\text { disease- } 148 . \\
\text { Patients with severe } \\
\text { illness-2 }\end{array}$ & $\begin{array}{l}\text { HCQ showed no } \\
\text { significantly higher } \\
\text { negative conversion } \\
\text { probability }(85.4 \%) \text { than } \\
\text { control }(81.3 \%) \text { patients. } \\
\text { Adverse effects were } \\
\text { reported in HCQ group }\end{array}$ & $\begin{array}{l}\text { Adverse events in } \\
\text { control and HCQ } \\
\text { group were } \\
\text { reported in } 7 \text { and } 21 \\
\text { patients } \\
\text { respectively }\end{array}$ & $\begin{array}{l}\text { Shanghai, } \\
\text { Anhui, Hubei, } \\
\text { China }\end{array}$ & $\begin{array}{l}\text { Smaller sample size. } \\
\text { Not peer-reviewed. }\end{array}$ \\
\hline
\end{tabular}


Table 2. Cont.

\begin{tabular}{|c|c|c|c|c|c|c|c|c|c|}
\hline \multirow{2}{*}{ Investigation/Reference } & \multirow{2}{*}{$\begin{array}{l}\text { Investigation } \\
\text { Type/Design }\end{array}$} & \multicolumn{2}{|c|}{ Patients (Total No) } & \multirow{2}{*}{ Regimes } & \multirow{2}{*}{$\begin{array}{c}\text { Severity of } \\
\text { COVID-19 Disease }\end{array}$} & \multirow{2}{*}{ Results/Key Findings } & \multirow{2}{*}{ Comment } & \multirow{2}{*}{ Location } & \multirow{2}{*}{ Limitation } \\
\hline & & Con & HCQ & & & & & & \\
\hline Million M et al. (2020) & $\begin{array}{l}\text { Open-label trail, } \\
\text { Non-randomized, } \\
\text { Non-blinded }\end{array}$ & 0 & 1061 & $\begin{array}{l}\text { HCQ- } 200 \mathrm{mg}(3 \\
\text { X/day) for } 10 \text { days } \\
+500 \mathrm{mg} \text { AZM } \\
\text { (day-1), followed } \\
\text { by } 250 \mathrm{mg} \text { for } \\
\text { next } 4 \text { days }\end{array}$ & $\begin{array}{c}\text { Patients had } 20.5 \% \\
\text { and } 2.2 \% \text { moderate } \\
\text { and severity scores } \\
\text { respectively }\end{array}$ & $\begin{array}{l}\text { In } 10 \text { day regime, good } \\
\text { clinical results and } \\
\text { virological cure were } \\
\text { reported in } 973 \text { patients } \\
(91.7 \%) \text {. HCQ+AZM } \\
\text { treatment before } \\
\text { COVID-19 illness is } \\
\text { safe and has low } \\
\text { fatality rate in patients }\end{array}$ & $\begin{array}{c}\text { Majority of patients } \\
\text { had relatively mild } \\
\text { symptoms at start } \\
(95 \%) \text {, therefore, } \\
\text { only } 10 \text { patients } \\
(0.9 \%) \text { ) transferred to } \\
\text { the ICU, \& } 8(0.75 \%) \\
\text { patients died }\end{array}$ & $\begin{array}{l}\text { Marseille, } \\
\text { France }\end{array}$ & $\begin{array}{l}\text { Study design. } \\
\text { Incomplete data on } \\
\text { some patients. } \\
\text { Unsynchronized } \\
\text { diagnostic reports }\end{array}$ \\
\hline Mahevas M et al. (2020) & $\begin{array}{l}\text { Multi-centric, } \\
\text { Non-Randomized, } \\
\text { aim to emulate a } \\
\text { target trial }\end{array}$ & 97 & 84 & $\begin{array}{l}\text { HCQ- } 600 \mathrm{mg} \text { for } \\
\text { about } \sim 7-8 \text { days }\end{array}$ & $\begin{array}{l}\text { Most patients had } \\
\text { bilateral } \\
\text { pneumonia, and } \\
75 \% \text { moderate or } \\
\text { severe illness }\end{array}$ & $\begin{array}{c}\text { No significant relief } \\
\text { was observed in HCQ } \\
\text { group as compared to } \\
\text { control at day } 7 \text { in } \\
\text { hospitalized patients. } \\
\text { All comorbidities were } \\
\text { less frequent in the } \\
\text { HCQ group. }\end{array}$ & $\begin{array}{l}17(20 \%) \text { patients in } \\
\text { the HCQ group, } \\
\text { received } \\
\text { concomitant AZM, } \\
\text { while } 64(76 \%) \\
\text { received amoxicillin } \\
\text { and clavulanic acid. }\end{array}$ & $\begin{array}{l}\text { Créteil, } \\
\text { Suresnes, } \\
\text { Evry, and } \\
\text { Paris, France }\end{array}$ & $\begin{array}{l}\text { Not peer-reviewed. } \\
\text { No randomization, } \\
\text { Unbalanced } \\
\text { prognostic variables } \\
\text { across hospitals. }\end{array}$ \\
\hline Magagnoli J et al. (2020) & $\begin{array}{c}\text { Retrospective } \\
\text { analysis, } \\
\text { Non-randomized }\end{array}$ & 158 & $\begin{array}{c}97 \text { (HCQ), } \\
113 \\
\text { (HCQ+AZ) }\end{array}$ & - & $\begin{array}{l}\text { All confirmed } \\
\text { COVID-19 patients. } \\
\text { No severity was } \\
\text { specified }\end{array}$ & $\begin{array}{l}\text { No evidence of HCQ } \\
\text { either with or without } \\
\text { AZM, lessen the risk of } \\
\text { mechanical support in } \\
\text { patients }\end{array}$ & $\begin{array}{c}\text { Study comprises } \\
\text { only men aged over } \\
65 \text { years, most black } \\
\text { population }\end{array}$ & $\begin{array}{l}\text { Virginia, and } \\
\text { South } \\
\text { Carolina, USA }\end{array}$ & $\begin{array}{c}\text { Study design. Not } \\
\text { peer-reviewed. } \\
\text { Possibility of } \\
\text { selection bias. }\end{array}$ \\
\hline $\begin{array}{l}\text { Mathies D et al. (2020) } \\
\text {-Case report }\end{array}$ & Case report & 0 & 1 & $\begin{array}{l}\text { HCQ- } 400 \mathrm{mg} \text { for } \\
1 \text { st day, then } 200 \\
\mathrm{mg} \text { for remaining } \\
11 \text { days }\end{array}$ & $\begin{array}{c}\text { 77-year-old } \\
\text { COVID-19 positive } \\
\text { patient with a heart } \\
\text { transplant, } \\
\text { moderate } \\
\text { symptoms }\end{array}$ & $\begin{array}{l}\text { Patient with existing } \\
\text { dyspnea and dry cough, } \\
\text { showed no further } \\
\text { deterioration of the } \\
\text { clinical state post HCQ } \\
\text { medication. After } 12 \\
\text { days, all negative }\end{array}$ & $\begin{array}{l}\text { Patients survived } \\
\text { and discharged } \\
\text { from hospital after } \\
12 \text { days and had } \\
\text { symptoms }\end{array}$ & $\begin{array}{l}\text { Koblenz, } \\
\text { Germany }\end{array}$ & - \\
\hline $\begin{array}{l}\text { Lane JCE et al. (2020) } \\
\text {-Case series }\end{array}$ & $\begin{array}{c}\text { A multinational, } \\
\text { network cohort } \\
\text { and } \\
\text { self-controlled } \\
\text { case series study }\end{array}$ & $\begin{array}{l}\text { 310,350 } \\
\text { (SSZ) }\end{array}$ & $\begin{array}{c}\text { HCQ-956374 } \\
\text { HCQ+AZM- } \\
\text { 323122, } \\
\text { HCQ+ } \\
\text { AMX- } \\
351956\end{array}$ & - (variable) & $\begin{array}{l}16 \text { patients had } \\
\text { severe adverse } \\
\text { events }\end{array}$ & $\begin{array}{l}\text { No excess risk of severe } \\
\text { events was identified } \\
\text { when } 30-\text { day HCQ and } \\
\text { SSZ (sulfasalazine) } \\
\text { were compare. While, } \\
\text { AZM + HCQ increased } \\
\text { risk CVD and morality }\end{array}$ & $\begin{array}{l}\text { cardiovascular } \\
\text { complications in } \\
\text { HCQ+AZM group } \\
\text { are likely due to } \\
\text { synergistic effects } \\
\text { on QT length }\end{array}$ & $\begin{array}{l}\text { Germany, } \\
\text { Japan, USA } \\
\text { Netherlands, } \\
\text { Spain, \& UK. }\end{array}$ & $\begin{array}{l}\text { Not peer-reviewed. } \\
\text { Potential risk of } \\
\text { overlapping in } \\
\text { patient datasets, } \\
\text { variance in data }\end{array}$ \\
\hline
\end{tabular}

Abbreviations: HCQ, Hydroxychloroquine; CQ, Chloroquine; EC50, Effective Concentration; AZM, Azithromycin; SSZ, Sulfasalazine; AMX, Amoxicillin; CT, Computed tomography; NEWS, National early warning score; PCR, Polymerase chain reaction; ICU, Intensive care unit; QTc, Corrected Q and T wave. ${ }^{* *}$ Last 2 rows in the dark enlist details of clinical case report/series. 
Besides these clinical trials, one case report and one case series also tested the efficacy of HCQ in COVID-19 patients. In the first case report, Mathies et al. showed that, in a 77-year old moderately sick COVID-19 patient with a history of heart transplant, HCQ treatment restricted further deterioration in his clinical condition, and the patient was released from hospital after twelve days with negative viral load [106]. In a self-controlled case series study (presently in preprint), Lane et al. showed that, compared to the control group given either nothing or Sulfasalazine-SSZ, patient groups treated with HCQ, HCQ+AZM, or HCQ+AMX showed no risk of severe illness [107]. However, HCQ combination with AZM was shown to increase the risk of CVD and mortality in patients. The clinical outcome of HCQ efficacy against COVID-19 in these studies has so far mainly remained confusing and inadequate. Therefore, a need for well-designed, structured, randomized controlled trials is critical to precisely assess the benefits of HCQ against COVID-19.

\subsection{ACE2, Hydroxychloroquine, and SARS-CoV-2 Replication}

The steps of viral entry, replication, and protein synthesis/processing are key druggable targets for antiviral drugs (Figure 3A). In the context of the utility of quinines, Savarino et al. were first to suggest the benefits of HCQ and CQ for the treatment of SARS-CoV [90]. They postulated the involvement of endocytosis in viral entry and associated immune response, where the latter could be a result of the activation inflammatory cytokines contributing further to the severity of viral infection, and therefore hinted at the potential benefits of HCQ and CQ to intervene in the underlying mechanism [90]. An in vitro study by Kayaerts et al. in the subsequent year confirmed the potency of CQ in inhibiting SARS-CoV replication in Vero E6 cells [16], whereas, Vincent et al. showed a dose-dependent inhibition of viral replication in Vero E6 cells, in both cases, either immediate or 3-5 h post-viral infection [15]. Of note, they showed that CQ treated cells had a lesser viral infection, and CQ could impair the terminal glycosylation of the ACE2 receptor, reducing SARS-CoV-ACE2 affinity and eventually diminishing the infection rate. These results emphasized the utility of HCQ for coronavirus prophylaxis [15]. Multiple recent in vitro reports as described in the earlier section $[18,19,85,100]$ further implicated the role of HCQ in the inhibition of SARS-CoV-2 replication. However, we presently lack molecular insights into the mode of action of HCQ/CQ against SARS-CoV-2. Learning from available evidence of its function primarily involves three aspects of its antiviral functions including: (i) inhibition of viral entry by affecting receptor glycosylation, (ii) control of virus replication by abolishing the $\mathrm{pH}$-dependent endosome-mediated viral entry, and (iii) restriction of viral protein's post-translational modification.

Kwiek and colleagues earlier revealed that QC could attenuate viral infection by interfering with the pre-entry step of viral recognition on the host cell receptor [108] (Figure 3A). Mechanistically, CQ was found to inhibit the function of quinone reductase 2 [108], a close structural relative of the UDP$\mathrm{N}$-acetylglucosamine 2- epimerases [109] enzyme that plays a critical function in sialic acid biosynthesis. Sialic acids are acidic monosaccharides that are frequently found at the edge of sugar chains of many transmembrane receptors/proteins and facilitate ligand binding. Of note, orthomyxoviruses and human coronavirus HCoV-O43 utilize sialic acid moieties as receptor components. Therefore, the potent sialic acid biosynthesis inhibitory function of HCQ/CQ was marked as crucial for its broad antiviral spectrum activities [110]. Attenuated binding of SARS-CoV in CQ treated cells in vitro may substantially implicate the role of CQ in interrupting the glycosylation of host cell receptor, viz., ACE2 in Vero E6 cells [15] (Figure 3A). 


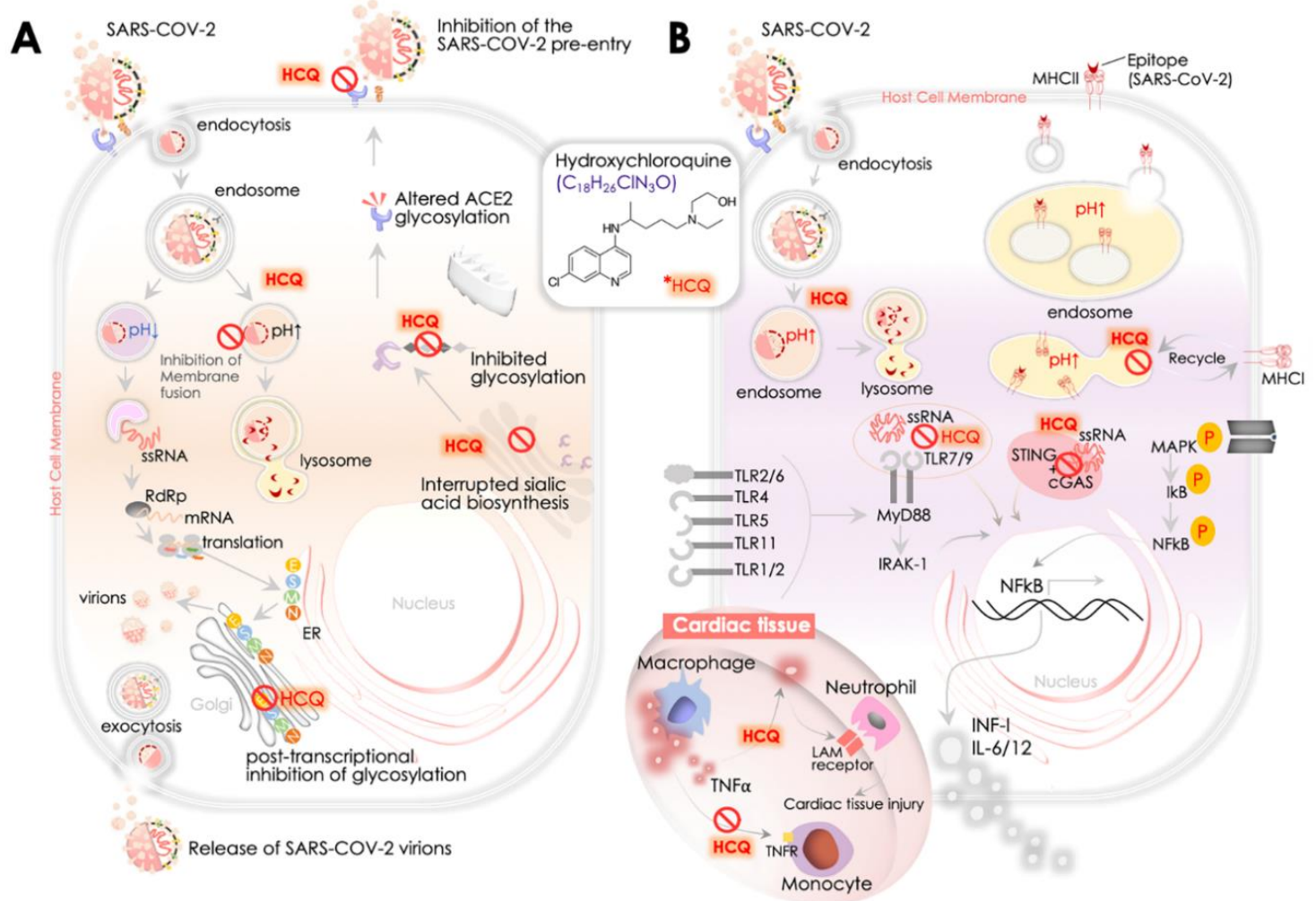

Figure 3. Hydroxychloroquine (HCQ): SARS-CoV-2 replication and immunomodulatory activities -proposed mechanism. (A) HCQ impacts the binding of SARS-CoV-2 S-protein and ACE2 receptor at the host cell surface by altering the ACE-2 n-terminal glycosylation. HCQ restricts SARS-CoV-2 infection by increasing endosomal $\mathrm{pH}$ that disrupts SARS-CoV-2 envelope fusion (requires acidic $\mathrm{pH}$ ) with endosome membrane phospholipids and subsequent release of its sRNA genome. This is a crucial step that could intervene in its further replication/transcription by RNA-dependent RNA polymerase (RdRp, viz., nsp12) and synthesis of its spike (S), membrane (M), envelope (E), nucleocapsid $(\mathrm{N})$, and nsp3 (a replicase complex component). SARS-CoV-2 infection exploits host cell's ribosome machinery to synthesize its non-structural proteins (NSPs) that constitutes a replicase-transcriptase complex that is enrolled further to synthesize its sub-genomic RNA. Viral proteins get translated in ER and processed in Golgi before assembling into the nucleocapsid and budding it as a mature virion. HCQ is postulated to alter the maturation of M protein at Golgi, resulting in the collapse of viral assembly. Besides interrupting glycosylation of the ACE2 receptor, HCQ also seems to restrict biosynthesis of the sialic acids that play a part in host cells binding with SARS-CoV-2. The role of HCQ is also implicated in attenuating the activation of mitogen-activated protein (MAP) kinase that could further impact viral replication. (B) HCQ modulates immune function and reduces inflammation. HCQ-led increase in endosomal $\mathrm{pH}$ impacts MHC Class I and II antigen cross-presentation. It alters the preparation and development of SARS-CoV-2 Ag-specific T-cells and B-cells. HCQ also impacts the onset of cytokine release from the innate immune system by attenuating DNA/RNA interaction and by activation of cGAS/STING signaling and by disrupting binding to TLR7/9 by increasing the endosomal $\mathrm{pH}$. HCQ impact on these axes further attenuates NFkB nuclear function in promoting the expression of pro-inflammatory cytokine (IFN I, IL-6, IL-12 etc.). In the cardiac tissue, HCQ also attenuates TNF $\alpha$ production in the macrophages and thereby reduces expression of TNFR (TNF $\alpha$ receptor)- $1 / 2$ at the membrane of nearby monocytes, which further restricts TNF $\alpha$ 's role in the extravasation of neutrophils that supports opening up the tight junctions of vascular endothelial cells and stimulates leukocyte adhesion molecules (LAM) expression.

The second important aspect of the HCQ/CQ mode of action is inhibition of virus replication by abolishing the $\mathrm{pH}$-dependent endosome-mediated viral entry at an early step (Figure 3A). Of note, 
a CQ-dependent increase in endosomal $\mathrm{pH}$ impacts cellular iron metabolism and restricts its release from transferrin in the endosome that leads to declined intracellular iron concentration [111]. This iron deficiency alters the function of several proteins/enzymes, primarily impacting the cellular replication and transcription machinery [111,112]. Early reports of HCQ/CQ increasing endosomal pH and stalling viral replication came from enveloped viruses, viz., Chikungunya virus (CHIKV) or Dengue virus (DENV) $[113,114]$. Prophylactic treatment of CQ to Vero E6 cells in vitro before virus exposure was shown to alkylate endosomal $\mathrm{pH}$ and attenuate viral infection effectively [115]. The underlying mechanism of the above HCQ/CQ activity included inhibition of endocytosis, shift in endosomal pH, and impaired virus-endosome fusion [116]. The impact of HCQ/CQ was also seen on the binding of SARS-CoV to its DC-SIGN receptor [116]. The function of HCQ or CQ in the endosome is suggested to impact on the activation step where acidic $\mathrm{pH}$ facilitates viral and endosomal membrane fusion and subsequent SARS-CoV genome release into the cytoplasm [117] (Figure 3A). The function of the lysosomal compartment that retains acidic $\mathrm{pH}$ in viral membrane fusion and release of its genome is compromised due to the activity of HCQ/CQ weak bases [118]. The inhibitory effect of CQ on membrane fusion and uncoating was also shown to impair the replication of the hepatitis A virus [119].

The role of these quinolones is further implicated in impairing the post-translational modification of newly synthesized viral proteins. This process also requires low $\mathrm{pH}$ for optimal proteolytic enzymes and glycosyltransferases activities in the endoplasmic reticulum (ER) or at the adjoining trans-Golgi network vesicles (Figure 3A). The reports investigating anti-retroviral activities of CQ attributed its inhibitory effect to the gp120 envelope protein glycosylation, producing non-infectious newly synthesized human immunodeficiency viruses (HIV) proteins [120]. Similarly, CQ interferes in proteolytic processing of the flavivirus prM glycoprotein of the Dengue-2 (DENV-2) virus [121], thereby impairing its infectivity. The impact of CQ on the post-translational modification process was also attributed to impair budding of the herpes simplex virus (HSV) by accumulating the unprocessed HSV-1 virions in the trans-Golgi network [122]. Of note, animal (murine/feline) coronavirus M protein was earlier shown to determine the intracellular budding site for its virions that is reflected in its congregation in the Golgi complex [123]. Its assembly beyond the site of budding suggests a possible mode of CQ action from its antiviral activity in SARS-CoV-2 replication inhibition. A recent report finding a trans-Golgi network localization signal in the C-terminal domain of $\mathrm{M}$ protein in the MERS-CoV virus [124] essentially reaffirmed the regulatory role of M protein in intracellular budding of virions and therefore marked its potential as a drug for the potential effect of quinolones.

\subsection{SARS-CoV-2, ACE2, and HCQ-Mediated Immunomodulatory Response}

The immunomodulatory and anti-inflammatory activities of HCQ were recognized earlier due to its benefits in autoimmune diseases such as systemic lupus erythematosus (SLE) and rheumatoid arthritis (RA) [90]. At the molecular level, HCQ was shown to impair antigen processing in lysosome by antigen-presenting cells that reduce the recruitment of T-cells and expression of pro-inflammatory cytokines, viz., IL-6 and TNF $\alpha$ [125] (Figure 3B). Multiple reports earlier underlined the anti-inflammatory activity of CQ/HCQ that include its inhibitory effect on IL-1 $\beta$ in THP-1 cells [126], IL-1, IL-6, and TNF $\alpha$ cytokine expression in monocytes/macrophages $[125,127]$. In the Dengue-2 virus-infected U937 cells, CQ was shown to inhibit IFN $\alpha$, IFN $\beta$, IFN $\gamma$, IL-6, IL-12 and TNF $\alpha$ gene expression [128]. CQ/HCQ-mediated reduced secretion of pro-inflammatory TNF $\alpha$ cytokine was particularly validated in a murine macrophage cell line [129], mouse peritoneal macrophages [130], and also in human peripheral blood mononuclear [131] and whole blood cells [132]. TNF $\alpha$, by activating monocytes, facilitates neutrophil extravasation by relieving tight junctions that further stimulate the expression of leukocyte adhesion molecules (LAM) aligned through human vascular endothelial cells [133]. Therefore, CQ/HCQ -led inhibition of TNF $\alpha$ is a significant event in its immunomodulatory activity. Besides inhibiting the TNF $\alpha$ production of activated monocyte-macrophages, CQ/HCQ was also found to reduce the expression of TNF receptors (TNFR 1 and 2) at the human monocytic cell 
surface, decreasing monocyte activation and leukocyte extravasation, thereby impairing TNFR-driven TNF $\alpha$ signaling [134] (Figure 3B).

Although immunomodulatory responses of HCQ are evident, its activities were not considered immunosuppressive and also showed no association with an elevated risk of infection [135]. The clinical outcome from multiple patient cohorts with rheumatologic disease showed a lack of immunosuppressive activities of HCQ, even in the long run, that could potentiate risk of any infection [135-137]. In the context of viral infection, HCQ was shown to impact on the innate immune response by disrupting vesicle acidification as an antiviral activity. A usual innate immune response of the host to SARS-CoV-2 comprises suppression of type I interferon. Toll-like receptor (TLR)-7 was recently shown to be involved in recognizing the SARS-CoV-2 RNA and subsequently stimulating the innate immune function in COVID-19 patients [138]. HCQ was shown to reduce the affinity of TLR-7 \& TLR-9 to viral genome/RNA by raising endosomal $\mathrm{pH}$ leading to the restricted release of key cytokines, e.g., INFs, IL-6, \& IL-12 (Figure 3B). Of note, no impact of CQ on MyD88-dependent signaling was observed, but its modulation by SARS-CoV was suggested to provide benefits in a murine challenge model [139]. HCQ also impairs cGAS (cyclic GMP-AMP synthase) function, which is essential for the production of type I interferon (IFN $\beta$ ) and can be activated by RNA/DNA dependent mechanism [140] (Figure 3B). While SARS-CoV activates CGAS/STING, SARS-CoV-2 was found to be highly responsive to IFN $\beta$ [141,142]. Furthermore, HCQ is shown to attenuate the cytotoxic function of NK cells by controlling perforin processing to its active form [143]. This evidence suggested the involvement of $\mathrm{HCQ} / \mathrm{CQ}$ in a modulation of the innate immune response in the host that is of significant clinical value. However, a precise readout of its molecular activity against SARS-Cov-2 warrants further careful investigation.

Multiple reports also revealed the effect of HCQ on the adaptive immune response. HCQ-induced increase in endosomal $\mathrm{pH}$ affects the processing and presentation of viral antigen that further attenuates $\mathrm{T}$ - and B-cell activation. CQ/HCQ treatment was also shown to decrease the count of prolific T-cells and control differentiation for Th1 and Th17 [144,145]. Interruption of antigen presentation by CQ/HCQ restricts activation of CD4 helper T-cells marked by CD154 expression, leading to reduced IL-6 and $\mathrm{TNF} \alpha$ production [146]. CQ treatment causing inhibition of autophagy during T-cell activation was found to reduce the T helper cell's response to antigen re-presentation, its proliferation, and IL-2 production [147]. Further, p38 mitogen-activated protein kinase (MAPK) inhibitory activity of CQ in the human monocytic cell line (THP-1) [126] affirmed results of an earlier finding that showed CQ-induced control on viral replication involves p38 MAPK inhibition [94] (Figure 3B). These results are critical in light of the fact that viruses require cell activation via MAPK signaling to achieve their replication cycle [148]. Although the available data so far primarily hints at the role of HCQ/CQ in attenuating the host's innate immune and adaptive immune responses and reducing the collection of T-cells and B-cells produced in response to SARS-CoV-2, efforts to elucidate the molecular mechanism of $\mathrm{CQ} / \mathrm{HCQ}^{\prime} \mathrm{s}$ activity in a case-specific manner, along with dosing, duration, and stage of disease, warrant careful further investigation.

\section{ACE2, HCQ, and Clinical Outcomes: Assessing Cardiovascular Risk and Benefits}

ACE2 has been central to SARS-CoV-2 pathology in the ongoing COVID-19 outbreak. Besides serving as a key component of RAS signaling in the cardiovascular system, several factors were shown to affect ACE2 functioning and, therefore, could impact on the clinical outcome of COVID-19 patients. Taking ACE2 into account, there are growing concerns about the ongoing repurposing of CQ/HCQ at enormous scale in clinics, insisting on the assessment of potential risk factors affecting ACE2 and HCQ repurposing regarding cardiovascular function. In this section, we discuss these aspects, readouts from available clinical outcomes, and the state of ongoing therapeutic regimes in current clinical trials. 


\subsection{ACE2 and Potential Cardiovascular Risk Factors}

SARS-CoV-2 binding to ACE2 is suggested to cause loss of the latter and also alters its function, which eventually develops into the pathophysiology of cardio-respiratory failure [149]. Results from animal studies showed that loss of ACE2 promotes reactive oxygen species (ROS) production via NADPH oxidase 2 activation, while recombinant ACE2 administration was shown to attenuate Ang II function in TGF $\beta 1$ and collagen production [150]. Similarly, the expression of recombinant ACE2 was found to diminish the risk of pulmonary artery hypertension pathophysiology [151]. Of note, the inability of the loss of ACE2 function to manage the deleterious effects of Ang II was found to impair cardiac and pulmonary structure and function [152]. It is, therefore, argued that Ang II receptor inhibitors/blockers may potentially serve a cardio-protecting function in the later phases of COVID-19 disease. A recent study comparing circulatory levels of Ang II in healthy controls and COVID-19 patients demonstrated its significantly higher expression in the latter, which was found to be consistent with lower ACE2 levels [41]. These results thereby conferred the crucial role of ACE2 in balancing Ang I and Ang II levels. Of note, Ang II circulatory levels correlated well with viral load and negative cardio-respiratory function in the SARS-CoV-2 patient cohort [41]. The role of PARP in the modulation of ACE2 was also implicated in hypertensive rats, where inhibition of PARP could enrich ACE2 protein levels [153]. These data could explain the high prevalence (15-40\%) of hypertension in COVID-19 patients [2,154] that increases further with disease severity [154]. Therefore, it conferred a crucial role to ACE2 and its function as a potential risk factor impacting CV function in COVID-19 patients (Figure 4).

Analyses of environmental and lifestyle-related factors were earlier shown to impact on ACE2 expression and function [155-158]. Results from animal studies showed a 100-fold increased ACE2 activity post NO2 exposure that also revealed a higher Ang II binding to its receptor $[155,156]$. Therefore, the role of ACE2 expression with Ang II binding to the AT1R was observed (Figure 4). These findings were confirmed by a population-based, cross-sectional survey that revealed an increased risk of hypertension with elevated exposure to NO2 in a population in China [159]. Data from the 2003 SARS epidemic further marked a positive association between air pollution and patient mortality in the Chinese population [160]. In the context of air pollution/NO2 levels, lockdown measures in the ongoing COVID-19 pandemic are suggested to benefit health, but high COVID-19 mortality was reported in areas with high NO2 pollution. Smoking was also suggested to be a key factor that may potentiate susceptibility to SARS-CoV-2 infection. Nicotine increases the expression of detrimental ACE, while reduced levels of compensatory ACE2/Ang (1-7) receptor axis were concurrently observed [157] (Figure 4). Although HCQ-mediated inhibition of ACE2 receptor glycosylation and the action of nicotine exerts control over ACE2's SARS-CoV-2 binding, a recent clinical meta-analysis data denied association of latter with disease severity [157] (Figure 4).

The ACE2 gene is localized at the X chromosome and shows polymorphism (Figure 4). A significant correlation between ACE2 polymorphism and incidences of arterial hypertension is reported for women and associated with different ethnicity, race, and locality in Han Chinese men [161,162]. The ACE2 polymorphism distribution in the Chinese population varied with regions and was found to be associated with different blood pressure responses, while northern regions in China had an elevated response compared to the southern regions. This polymorphism was suggested to be a result of different climatic conditions, acquired by adaptive selection in populations over the generations [161,163]. The ACE1 and ACE2 polymorphism in Brazilian patients was also found to be associated with hypertension [164]. Furthermore, in Asian populations, ACE2 polymorphism was found to be correlated with the prevalence of cardiovascular comorbidities [71]. However, no evidence of its correlation with different susceptibility to SARS-CoV-2 infection or its severity is yet known. The geographical and ethnic distribution of ACE2 polymorphisms is also suggested to vary susceptibility to SARS-CoV-2 infection (Figure 4). 
A

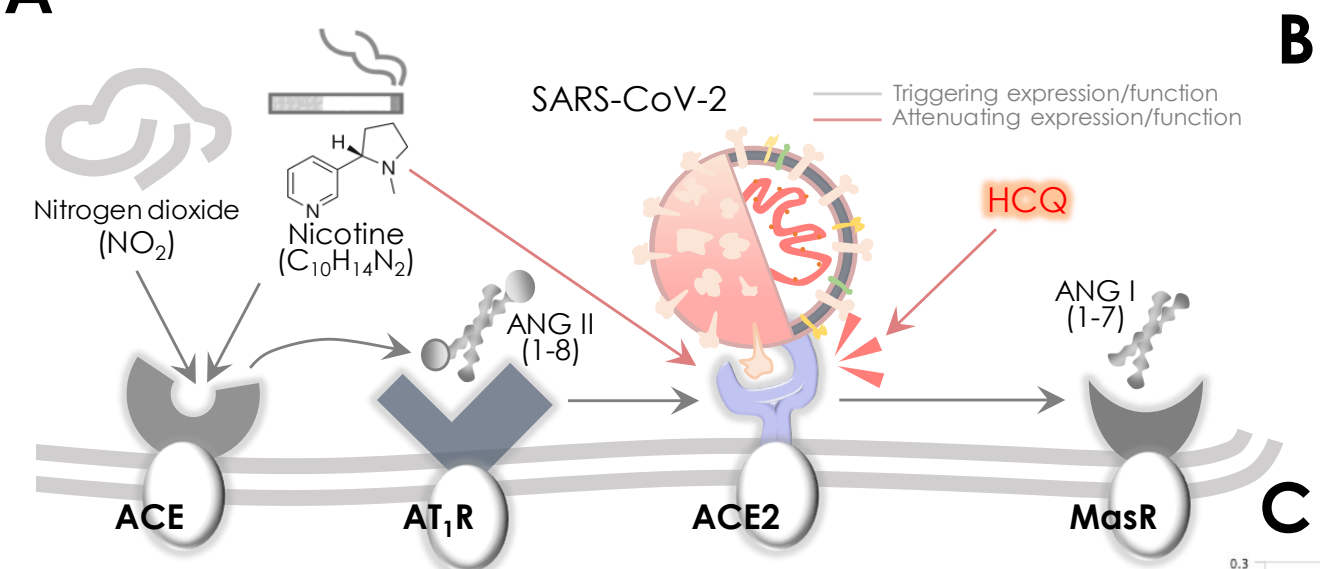

B

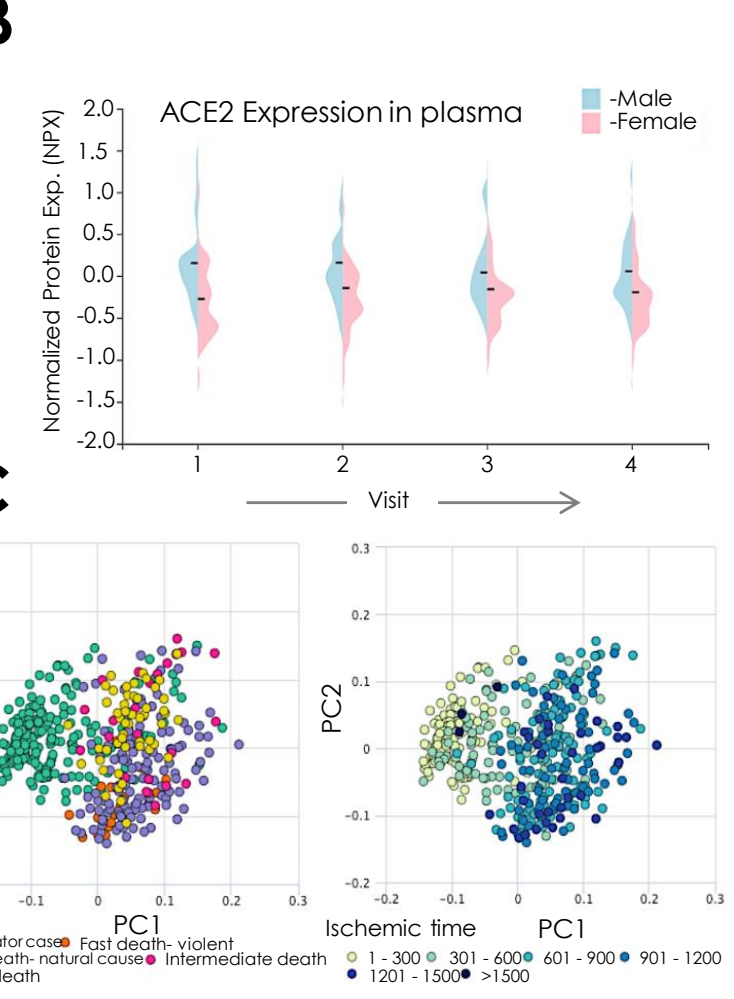

Figure 4. SARS-CoV-2, ACE2, and potential cardiovascular risk factors: assessing the vulnerability of COVID-19 infection. (A) Schematic diagram showing the risk of NO2 and nicotine in the modulation ACE2 expression, wherein levels of ACE2 and ratio of Ang II/Ang 1-7 determine the cardiovascular pathology. NO2 might increase, while nicotine might decrease the ACE2 levels, and this could alter the ratio of Ang II/Ang 1-7 in the heart triggering hypertension and risk of SARS-CoV-2 infection. Other potential factors that could potentially alter ACE2 expression include its genetic polymorphism, geographic localization, ethnicity, age, gender, and varied protein stability. (B) Graph (violin plot; image credit: Human Protein Atlas) shows the normalized protein expression of ACE2 levels in the blood plasma samples of the control males and females, where a relatively higher ACE2 expression can be seen in males than the females. (C) Graphs showing a lower ACE2 protein stability during death (on Hardy scale) and ischemia (calculated aa ischemic time) (image credit: Human Protein Atlas). 
The factors that are apparently found to be linked with worse clinical outcomes in COVID-19 patients include the patient's age and gender [2]. Earlier, results from the animal study suggested an age-dependent decline of ACE2 levels in the lungs. However, a recent observation-based prospective report analyzing ACE2 activity in bronchoalveolar lavage fluid lacked any significant correlation with age [165]. Besides examining ACE2 clinical outcome, Guan et al. clearly showed that older patients (mean age- 63 years; range 53-71) are more prone to experience intensive care (ICU admission, requiring ventilation), or fatality than younger patients (Mean age- 46 years, range 35-57) [2]. A relatively higher (50-80\%) susceptibility of males to COVID-19 complications among hospitalized patients was also observed [5-8,166]. To check out the disparity of ACE2 level in males and females, we retrieved circulatory ACE2 expression (in the blood plasma, from healthy males and female controls) from the Human Protein Atlas (HPA; http://www.proteinatlas.org) (Figure 4). Normalized protein expression in plasma showed relatively higher levels of ACE2 in males than females (Figure 4), whereas analyses of protein levels during death and ischemia showed the distribution of ACE2 levels across Hardy scale and ischemic time (Figure 4).

\subsection{HCQ Therapeutics and its Impact on Cardiovascular Function}

The prophylactic and broad-spectrum benefits of HCQ/CQ in the absence of a SARS-CoV-2 specific antiviral or vaccine encouraged their large-scale clinical repurposing during the ongoing COVID-19 crisis [167]. Besides the growing therapeutic or ethical concerns about their yet unproven efficacy against SARS-CoV-2, potential risks of this medication should also be carefully assessed before clinical prescription $[168,169]$. The potentially detrimental effects of HCQ on cardiovascular function are known as primitive clinical outcomes. HCQ/CQ is known to produce mild cellular and cardiac toxicities. A systematic review assessing cardiac complications in HCQ/CQ treated patients for an extended period revealed conduction disorders as the leading side effect [170]. Other unfavorable cardiac outcomes included hypertrophy, heart failure, hypokinesia, valvular dysfunction, and pulmonary arterial hypertension. However, the above adverse outcomes improved in a significant number of patients $(44.9 \%)$ upon HCQ/CQ withdrawal, while the remaining had irreversible events $(12.9 \%)$ or mortality (30.8\%) [170]. Cardiac conduction disorders are the leading cause of arrhythmia that underlined the proarrhythmic activity of $\mathrm{HCQ} / \mathrm{CQ}$, and it was suggested to inhibit the cardiac inward rectifier $\mathrm{K}+$ current (Kir/IK1) and subsequently to induce lethal ventricular arrhythmia. These effects were partly seen with the attenuated human ether-à-go-go related gene (hERG) and Kir2.1 potassium channel activity that may be acquired at a low HCQ/CQ concentration [171,172]. The clinical readouts of HCQ/QC usage exhibit signs of QTc prolongation and risk of ventricular arrhythmias [173]. Although the occurrence of QTc prolongation in the setting of HCQ/CQ is yet to be interpreted correctly, its ECG readouts need to distinguish HQ outcome carefully to avoid a potential overlapping with existing cardiovascular comorbidities in COVID-19 patients. In a cohort of healthy participants, lower $(600 \mathrm{mg})$ and higher $(1500 \mathrm{mg})$ doses of CQ were shown to impact by causing an average $16 \mathrm{~ms}(95 \% \mathrm{CI}$ : 9-23 ms) and $28 \mathrm{~ms}$ (95\% CI: 18-38 ms) increase in QTc respectively [174], while the most significant QTc prolongation occurred four hours after being given the second dose. A combination of HCQ and azithromycin (AZM) for SARS-CoV-2 treatment was shown to significantly prolong the QTc interval over time in a cohort of 84 patients, where $18 \%$ showed a QTc increase by $40-60 \mathrm{~ms}$, and $12 \%$ QTc $>60 \mathrm{~ms}$, while $11 \%$ overall showed QTc $>500 \mathrm{~ms}$, reflecting the risk of arrhythmia [175]. Amid contrary clinical outcomes of HCQ and AZM usage, where Gautret et al. showed the benefit [22], and Molina et al. [23] denied such effect of its treatment with COVID-19 patients, prescription of HCQ and AZM usage might impose further cardiovascular risk in the outpatient setting. In a retrospective study enrolling the population receiving HCQ for rheumatic disease, an increased risk of cardiovascular mortality in HCQ and AZM treated group over the HCQ and amoxicillin (AMX) treated group was observed [107]; however, overall mortalities were indifferent. On a similar note, application of lopinavir/ritonavir, a protease inhibitor that is frequently used for treating HIV infection and has exhibited an in vitro 
activity against SARS-CoV, showed no benefit/decrease in SARS-CoV-2 viral load in a 14 day open-label randomized trial [176], yet it is still being used with or without CHQ in some settings against COVID-19.

\subsection{HCQ Repurposing and Heart: Therapeutic Regimes in Current Clinical Trials}

Amid accelerated repurposing of HCQ/CQ for COVID-19, concerns of their safety in clinical practice are continually growing. An array of unsatisfactory clinical studies (patient cohort, perspectives, case reports) by date, showing mixed positive or negative results further made it crucial to determine the clinical outcome of $\mathrm{CHQ} / \mathrm{CQ}$ repurposing. As a result, numerous randomized clinical trials evaluating the suitability of HCQ/CQ for COVID-19 were proposed and initialized worldwide. At present, out of 1717 registered clinical trials of COVID-19 at US NIH's National Library of Medicine portal (https://www.clinicaltrials.gov/ct2/home) from all over the world, 206 studies are evaluating the prophylactic and therapeutic efficacy of $\mathrm{HCQ} / \mathrm{CQ}$. While surveying trials for an additional term "cardiovascular or heart", 13 trials were found to be explicitly testing the efficacy of HCQ with an emphasis on cardiovascular safety in pre- and post-treatment settings. Table 3 lists all of these studies, and further information can be accessed at NIH's ClinicalTrial.Gov portal.

Studies from China, including those of Wang et al. [19] and Gao et al. [24], earlier supported the repurposing of HCQ/CQ for COVID-19 treatment, by stating HCQ's superiority over control treatments in shortening the disease course. Presently, out of 666 ongoing clinical trials in China on COVID-19, 13 trials are evaluating the use of HCQ for COVID-19, further information of which can be accessed at the ChiCTR portal (http://www.chictr.org.cn/enindex.aspx). Besides the reports backing CHQ repurposing $[19,22,24]$, multiple hospitals/institutes worldwide have constituted guidelines for HCQ usage and assimilated instructions provided by the Centers for Disease Control and Prevention (CDC, USA) (available at https://www.cdc.gov/coronavirus/2019-ncov/hcp/therapeutic-options.html) describing the treatment regime and clinical relevance of HCQ in the COVID-19 pandemic. Recently, a clinical study from the University of Oxford and the National Health Service (NHS, U.K.) revealed "no beneficial effect" of HCQ in an inpatients randomized trial. Subsequently, this finding and existing data on HCQ led WHO to halt its Solidarity Trial that was planned to estimate its efficacy, along with other potential treatment arms. Furthermore, citing lack of a clear HCQ benefit, NIH also ceased its ORCHID trial after an interim review by an independent data monitoring committee, whereas a lack of active enrollment and safety concerns further paused clinical trials of generic HCQ makers Novartis and Sanofi, respectively. Although these recent developments dashed hopes of HCQ utility for COVID-19 patients, several institute or investigator-backed trials are still underway and may further shed light on HCQ's function. 
Table 3. Table listing ongoing clinical studies investigating the efficacy of HCQ in therapeutic and prophylactic settings with an emphasis on cardiovascular concerns.

\begin{tabular}{|c|c|c|c|c|c|c|c|c|c|}
\hline Trail Identifier & Study Title & $\begin{array}{c}\text { Study } \\
\text { Type/Design }\end{array}$ & Study Phase & $\begin{array}{c}\text { Volunteers } \\
\text { (Active) }\end{array}$ & Interventions/Drug(s) & $\begin{array}{c}\text { Active } \\
\text { Comparator }\end{array}$ & Primary Outcome & Location & $\begin{array}{l}\text { Study } \\
\text { Sponsor }\end{array}$ \\
\hline NCT04371926 & $\begin{array}{l}\text { Prophylactic Benefit of } \\
\text { HCQ in COVID-19 Cases } \\
\text { with Mild to Moderate } \\
\text { Symptoms and in } \\
\text { Healthcare Workers with } \\
\text { High Exposure Risk } \\
\text { (PREVENT) }\end{array}$ & $\begin{array}{l}\text { Interventional, } \\
\text { Randomized }\end{array}$ & - & 64 & $\begin{array}{l}\mathrm{HCQ}, 400 \mathrm{mg} \text { (day-1), then } 200 \\
\text { mg for next } 4 \text { days (b.i.d.) }\end{array}$ & No-HCQ arm & $\begin{array}{l}\text { Prophylactic Benefit } \\
\text { of HCQ in patients } \\
\text { and healthcare } \\
\text { workers }\end{array}$ & - & $\begin{array}{l}\text { Texas Cardiac } \\
\text { Arrhythmia } \\
\text { Research } \\
\text { Foundation }\end{array}$ \\
\hline NCT04341441 & $\begin{array}{l}\text { Will Hydroxychloroquine } \\
\text { Impede or Prevent } \\
\text { COVID-19 (WHIP } \\
\text { COVID-19) }\end{array}$ & $\begin{array}{l}\text { Interventional, } \\
\text { Randomized }\end{array}$ & Phase 3 & 3000 & $\begin{array}{l}\text { HCQ, } 400 \mathrm{mg} \text { (day-1), then } 200 \\
\text { mg for a week (b.i.d.) }\end{array}$ & Placebo & $\begin{array}{l}\text { Use of HCQ as a } \\
\text { preventive therapy } \\
\text { against COVID-19 }\end{array}$ & United States & $\begin{array}{l}\text { Henry Ford } \\
\text { Health System }\end{array}$ \\
\hline NCT04371744 & $\begin{array}{l}\text { AI for QT Interval } \\
\text { Analysis of ECG From } \\
\text { Smartwatches in Patient } \\
\text { Receiving Treatment for } \\
\text { Covid-19 (QT-Logs) }\end{array}$ & $\begin{array}{l}\text { Observational, } \\
\text { Cohort, } \\
\text { Prospective }\end{array}$ & - & 100 & Not Applicable & - & $\begin{array}{c}\text { Measurement of QTc } \\
\text { using an AI and ECG } \\
\text { data via } \\
\text { smartwatches, } \\
\text { compare to standard } \\
12 \text { leads ECG }\end{array}$ & $\begin{array}{l}\text { Marseille, } \\
\text { France }\end{array}$ & $\begin{array}{l}\text { Assistance } \\
\text { Publique } \\
\text { Hopitaux De } \\
\text { Marseille }\end{array}$ \\
\hline NCT043329 & $\begin{array}{l}\text { Outcomes Related to } \\
\text { COVID-19 treated with } \\
\text { HCQ Among In-patients } \\
\text { with Symptomatic } \\
\text { Disease (ORCHID) }\end{array}$ & $\begin{array}{l}\text { Interventional, } \\
\text { Randomized }\end{array}$ & Phase 3 & 510 & $\begin{array}{l}\text { HCQ, } 400 \text { mg (day- } 1 \text { ), then } 200 \\
\text { mg for next } 5 \text { days (b.i.d.) }\end{array}$ & Placebo & $\begin{array}{l}\text { Determine the } \\
\text { COVID Ordinal Scale } \\
\text { for patients on day } 15\end{array}$ & United States & $\begin{array}{l}\text { Massachusetts } \\
\text { General } \\
\text { Hospital }\end{array}$ \\
\hline NCT04353245 & $\begin{array}{l}\text { Study of Biomarkers in } \\
\text { the Long-term Impact of } \\
\text { Coronavirus Infection in } \\
\text { the Cardiorespiratory } \\
\text { System (PostCOVID19) }\end{array}$ & $\begin{array}{l}\text { Observational } \\
\text { [Registry], } \\
\text { Case-Control }\end{array}$ & - & 130 & Arm treatment $(\mathrm{HCQ}+\mathrm{AZM})$ & - & $\begin{array}{l}\text { Fibrosis on cardiac } \\
\text { resonance and/or } \\
\text { decreased functional } \\
\text { capacity on } \\
\text { ergo-spirometry }\end{array}$ & $\begin{array}{l}\text { São Paulo, SP, } \\
\text { Brazil }\end{array}$ & $\begin{array}{l}\text { University of } \\
\text { Sao Paulo } \\
\text { General } \\
\text { Hospital }\end{array}$ \\
\hline NCT04372082 & $\begin{array}{l}\text { Hydroxychloroquine or } \\
\text { Diltiazem-Niclosamide } \\
\text { for the Treatment of } \\
\text { COVID-19 (HYdILIC) }\end{array}$ & $\begin{array}{l}\text { Interventional, } \\
\text { Randomized }\end{array}$ & Phase 3 & 480 & $\begin{array}{c}\text { HCQ, } 2200 \mathrm{mg} \text { (t.i.d.) during } \\
10 \text { days in addition to SOC; } \\
\text { While niclosamide } 500 \mathrm{mg} \times 4 \\
\text { at J1 then } 500 \mathrm{mg} \text { (b.i.d.) }+ \\
\text { diltiazem } 60 \mathrm{mg} \text { (t.i.d.) during } \\
10 \text { days }\end{array}$ & $\begin{array}{c}\text { HCQ, } \\
\text { Diltiazem \& } \\
\text { Niclosamide }\end{array}$ & $\begin{array}{l}\text { Composite criteria- } \\
\text { death, clinical } \\
\text { worsening, and } \\
\text { assisted-ventilation }\end{array}$ & Lille, France & $\begin{array}{l}\text { University } \\
\text { Hospital, Lille, } \\
\text { France }\end{array}$ \\
\hline
\end{tabular}


Table 3. Cont

\begin{tabular}{|c|c|c|c|c|c|c|c|c|c|}
\hline Trail Identifier & Study Title & $\begin{array}{c}\text { Study } \\
\text { Type/Design }\end{array}$ & Study Phase & $\begin{array}{l}\text { Volunteers } \\
\text { (Active) }\end{array}$ & Interventions/Drug(s) & $\begin{array}{c}\text { Active } \\
\text { Comparator }\end{array}$ & Primary Outcome & Location & $\begin{array}{l}\text { Study } \\
\text { Sponsor }\end{array}$ \\
\hline NCT04361422 & $\begin{array}{l}\text { Isotretinoin in Treatment } \\
\text { of COVID-19 } \\
\text { (Randomized) }\end{array}$ & $\begin{array}{l}\text { Interventional, } \\
\text { Randomized }\end{array}$ & Phase 3 & 300 & $\begin{array}{l}\text { Isotretinoin, 13-cis retinoic acid } \\
0.5 \mathrm{mg} / \mathrm{kg} / \text { day b.i.d. for } 1 \\
\text { month. Sham compa- HCQ } \\
500 \mathrm{mg} / 12 \mathrm{~h} \& \text { other drugs }\end{array}$ & $\begin{array}{l}\text { Active Comp: } \\
\text { HCQ and } \\
\text { other drugs+ } \\
\text { isotretinoin }\end{array}$ & $\begin{array}{l}\text { Viral clearance and } \\
\text { COVID-19 virus load }\end{array}$ & $\begin{array}{l}\text { Tanta city, } \\
\text { Egypt }\end{array}$ & $\begin{array}{l}\text { Tanta } \\
\text { University, } \\
\text { Egypt }\end{array}$ \\
\hline NCT04374019 & $\begin{array}{l}\text { Novel Agents for } \\
\text { Treatment of High-risk } \\
\text { COVID-19 Positive } \\
\text { Patients }\end{array}$ & $\begin{array}{l}\text { Interventional } \\
\text { (Clinical Trial), } \\
\text { Randomized }\end{array}$ & Phase 2 & 240 & $\begin{array}{l}\text { HCQ } 200 \mathrm{mg} \text { (t.i.b.) for } 14 \text { days. } \\
\text { HCQ combination with AZM, } \\
\text { Ivermectin, and Camostat } \\
\text { Mesilate are also enrolled }\end{array}$ & - & $\begin{array}{l}\text { Proportion of patients } \\
\text { experiencing clinical } \\
\text { deterioration }\end{array}$ & $\begin{array}{l}\text { Kentucky, } \\
\text { United States }\end{array}$ & $\begin{array}{l}\text { Susanne } \\
\text { Arnold, } \\
\text { University of } \\
\text { Kentucky }\end{array}$ \\
\hline NCT04382625 & $\begin{array}{l}\text { Hydroxychloroquine in } \\
\text { SARS-CoV-2 (COVID-19) } \\
\text { Pneumonia Trial }\end{array}$ & $\begin{array}{l}\text { Interventional, } \\
\text { Randomized } \\
\text { (Open Label) }\end{array}$ & Phase 4 & 120 & $\begin{array}{l}\text { HCQ } 400 \mathrm{mg} \times 2(800 \mathrm{mg}) \text { then } \\
200 \mathrm{mg}, \text { t.i.b. }(600 \mathrm{mg} / 24 \mathrm{~h} \\
\text { period) starting } 8 \mathrm{~h} \text { after } 1 \mathrm{st} \\
\text { dose, total } 14 \text { doses over } 5 \text { days }\end{array}$ & - & $\begin{array}{c}\text { Data collection, } \\
\text { Change from Baseline } \\
\text { Oxygenation on Day } \\
1-5\end{array}$ & $\begin{array}{l}\text { Washington } \\
\text { SU, USA }\end{array}$ & $\begin{array}{l}\text { Kootenai } \\
\text { Health, } \\
\text { United States }\end{array}$ \\
\hline NCT04333355 & $\begin{array}{l}\text { Safety in Convalescent } \\
\text { Plasma Transfusion to } \\
\text { COVID-19 }\end{array}$ & $\begin{array}{l}\text { Interventional, } \\
\text { Open label }\end{array}$ & Phase 1 & 20 & Convalescent Plasma & - & $\begin{array}{l}\text { Adverse effects of } \\
\text { administration of } \\
\text { convalescent plasma }\end{array}$ & Mexico & $\begin{array}{l}\text { Hospital San } \\
\text { Jose Tec de } \\
\text { Monterrey, } \\
\text { Mexico } \\
\end{array}$ \\
\hline NCT04358068 & $\begin{array}{l}\text { Evaluating the Efficacy of } \\
\text { Hydroxychloroquine and } \\
\text { Azithromycin to Prevent } \\
\text { Hospitalization or Death } \\
\text { in Persons With } \\
\text { COVID-19 }\end{array}$ & $\begin{array}{l}\text { Interventional, } \\
\text { Randomized }\end{array}$ & Phase 2 & 2000 & $\begin{array}{c}\text { HCQ }(200 \times 2 \mathrm{mg} \text { day-1, then } \\
200 \mathrm{mg} \times 2 \text { for } 6 \text { days })+ \text { AZM } \\
(250 \mathrm{mg} \times 2 \mathrm{mg} \text { - Day } 0 \text {, then } \\
250 \mathrm{mg} \text { once daily for } 4 \text { doses } \\
\text { (4 days) }\end{array}$ & Placebo & $\begin{array}{l}\text { Proportion of } \\
\text { patients' mortality } \\
\text { with COVID-19 }\end{array}$ & $\begin{array}{l}\text { San Diego, } \\
\text { United States }\end{array}$ & $\begin{array}{l}\text { National } \\
\text { Institute of } \\
\text { Allergy and } \\
\text { Infectious } \\
\text { Diseases } \\
\text { (NIAID), USA } \\
\end{array}$ \\
\hline NCT04373044 & $\begin{array}{l}\text { Antiviral Therapy and } \\
\text { Baricitinib for the } \\
\text { Treatment of Patients } \\
\text { with Moderate or Severe } \\
\text { COVID-19 }\end{array}$ & $\begin{array}{l}\text { Interventional } \\
\text { (Clinical Trial), } \\
\text { Open label }\end{array}$ & Phase 2 & 59 & $\begin{array}{l}\text { 1) } \mathrm{HCQ}, \mathrm{PO} \text { t.i.d., 2) } \\
\text { lopinavir/ritonavir PO b.i.d., or } \\
\text { 3) remdesivir. }\end{array}$ & - & $\begin{array}{l}\text { Proportion of patients } \\
\text { requiring invasive } \\
\text { mechanical } \\
\text { ventilation or dying }\end{array}$ & United States & $\begin{array}{l}\text { University of } \\
\text { Southern } \\
\text { California, } \\
\text { United States }\end{array}$ \\
\hline NCT04349410 & $\begin{array}{l}\text { The Fleming [FMTVDM] } \\
\text { Directed CoVid-19 } \\
\text { Treatment Protocol } \\
\text { (FMTVDM) }\end{array}$ & $\begin{array}{l}\text { Interventional, } \\
\text { Randomized }\end{array}$ & $\begin{array}{l}\text { Phase 2, Phase } \\
3\end{array}$ & 500 & $\begin{array}{l}\mathrm{HCQ}, 200 \mathrm{mg} \text { po q } 8 \text { hrs }(600 \\
\text { mg qD) for 10-days, \& HCQ } \\
\text { regime with other drugs }\end{array}$ & - & $\begin{array}{l}\text { Improvement in } \\
\text { FMTVDM Analyzed } \\
\text { by nuclear imaging }\end{array}$ & United States & $\begin{array}{l}\text { The Camelot } \\
\text { Foundation, } \\
\text { USA }\end{array}$ \\
\hline
\end{tabular}

Abbreviations: HCQ, Hydroxychloroquine; $\mathrm{CQ}$, Chloroquine; AZM, Azithromycin; SCO, Standard of care; b.i.d., bis in die (twice a day, for HCQ dose); t.i.d., ter in die (trice per day); $\mathrm{QTC}$

Corrected Q and T wave; AI, Artificial intelligence, PO, Per os (Orally); ECG, electrocardiogram; FMTVDM, Fleming Method for Tissue and Vascular Differentiation and Metabolism. 


\section{COVID-19, ACE2, and HCQ: Consideration and Recommendations}

Preventive measures are the best approach against COVID-19. As noted, a higher level of ACE2 expression is associated with susceptibility to SARS-CoV infection in vitro, suggesting that the upregulated level of ACE2 promotes the risk of COVID-19 [177]. Ang II Receptor Blockers (ARBs) and ACE inhibitors (ACEIs) are promising candidates available for the treatment of CVD. Various studies suggest that ARBs and ACEIs increase ACE2 expression and inhibit ACE1 or block AT1R [178]. For COVID-19 patients, the termination of ARBs/ACEIs are not recommended as they block the RAS and protect patients against CV complications. Exogenous administration of recombinant ACE2 may be the most promising alternative to treat COVID-19 patients. Moreover, HCQ and AZM potentiated severe complications for patients with CVDs, which includes cardiac irregularities, e.g., arrhythmia, long QT syndrome, polymorphic ventricular tachycardia, along with increased risk of mortality. The combination of these two drugs on QT or arrhythmia has not yet been tested. The recommended dose for HCQ is $400 \mathrm{mg}$ twice daily, followed by $200 \mathrm{mg}$ twice daily for four days. Recommended dosage for azithromycin is $500 \mathrm{mg}$ twice daily for five days, and clinical trials for these agents at various doses are in progress [179-181]. These doses are not recommended for children less than 12 years, and pregnant or lactating women. Initial results suggest HCQ benefits in reducing in-hospital duration, decreasing pneumonia severity, and in rapid virus clearance [24]. However, these doses should be administered under close medical supervision. ECG monitoring is recommended to observe cardiac arrhythmias, including QT prolongation, atrioventricular blockage, and Torsade de Pointe. The American Heart Association (AHA), American College of Cardiology (ACC), and the Heart Rhythm Society (HRS) jointly published guidelines for health care professionals, which include measures to reduce or mitigate CVD risk in COVID-19 patients. These measures included: (1) withdrawal of HCQ and azithromycin in patients with baseline QTc prolongation (QTc, $\geq 500 \mathrm{~ms}$ ), (2) ECG/QT interval monitoring, (3) avoidance of other QTc prolonging agents whenever feasible, and (4) correction of hypokalemia $>4 \mathrm{mEq} / \mathrm{L}$ and hypomagnesemia $>2 \mathrm{mg} / \mathrm{dL}$. Standard quality care is a must for patients while testing the efficacy of HCQ/CQ for COVID-19. While these agents may work as monotherapy or in combination, one needs to consider the effect of these medications on COVID-19 patients with existing CVD. Given the fact that present knowledge is inadequate and lacks a clear explanation of the efficacy of HCQ/CQ in preventing virus transmission, especially for healthcare professionals, we believe that results from clinical trials will provide more information that will be crucial in curbing the risks involved in the COVID-19 pandemic.

\section{SARS-CoV-2, ACE2, and HCQ: The Way Forward}

The ongoing COVID-19 pandemic has considerably stressed the global healthcare system and pushed it to a crisis, while now, with time, we are started learning to live with it. Most importantly, the last three months have tested the competence, coordination, and policymaking of healthcare sectors across the globe and exposed our preparedness in the hour of crisis.

HCQ/CQ repurposing, beyond anecdotal benefits, may buy us time to develop targeted therapeutics against COVID-19. A SARS-CoV-2 specific vaccine or antiviral is more likely to succeed and may fill the void, rather than anecdotal alternatives. The anecdotal HCQ repurposing should not be rendered as a cure. Therefore, it demands randomized controlled trials at earliest to elucidate its clear and safe benefits regarding COVID-19. Voluntary participation in such ongoing clinical trials of controls and persons with CV comorbidities worldwide may help us in grasping clinical outcomes early and may swiftly determine HCQ/CQ efficacy and its clinical regimes. Importantly, to work out a safer HCQ regime for elderly or patients having CV comorbidities, a clear understanding of the impact of ARBs and ACEIs is critically required and therefore this should also be tested in clinical trials. This may help us mitigate the impact of CV comorbidities and their risks in the course of an adopted therapeutic regime. Analysis of the patient's RAS phenotype by its expression and function profiling, particularly for ACE2, before starting the treatment may also predict the critical involvement of ACE2 in SARS-CoV-2 severity and could tell us if ACEIs or ARBs could be of any help in the patient's 
recovery. It may also further help us understand in the future the risk of SARS-CoV-2 infection in the population having preexisting CVDs and high ACE2 levels. In the light of available evidence, more protection is desirable for patients with $\mathrm{CV}$ comorbidities, and thus they could be preferentially immunized with a COVID-19 vaccine in the future. Therefore, this emphasizes the need to develop a SARS-CoV-2 -specific vaccine at the earliest.

Another critical aspect that needs to be carefully addressed in the future is a follow-up on COVID-19 survivor's health. Elevated systemic inflammatory and incessant pro-coagulant activity persist in pneumonic patients even after discharge from the hospital. Clinical data suggest an association of pneumonia with increased risk of CDVs up to a decade after follow-up [182], which postulates a likely scenario for SARS-CoV-2 respiratory and CV infections. Similarly, a metabolic study showed disruption of lipid metabolism for twelve years after the clinical survival of 25 SARS patients [183]. Although factors including viral phenotype, severity, baseline characteristics and long-term prognosis may diversify the follow-up outcome, it is crucial to serially follow-up survivor's health to predict the prognostic outcome in COVID-19 patients, especially those with preexisting CV comorbidities.

Author Contributions: Conceptualization, R.S.K.; writing-original draft preparation, R.S.K., D.T., A.S.M., and R.K.; writing-review and editing, R.S.K., and D.T. All authors have read and agreed to the published version of the manuscript.

Funding: American Heart Association (AHA) grant number: 19CDA34490009, and National Institutes of Health (NIH) grant number: K99DK120876 to D.T.

Acknowledgments: The data used for the analyses described in this manuscript (Figure 2B,D) were obtained from the GTEx Portal on 05/13/20 and/or dbGaP accession number phs000424.vN.pN on 05/13/2020.

Conflicts of Interest: The authors declare no conflict of interest. The funders had no role in the design of the study; in the collection, analyses, or interpretation of data; in the writing of the manuscript, or in the decision to publish the results.

\section{References}

1. Zhou, P.; Yang, X.L.; Wang, X.G.; Hu, B.; Zhang, L.; Zhang, W.; Si, H.R.; Zhu, Y.; Li, B.; Huang, C.L.; et al. A pneumonia outbreak associated with a new coronavirus of probable bat origin. Nature 2020, 579, $270-273$. [CrossRef] [PubMed]

2. Guan, W.J.; Ni, Z.Y.; Hu, Y.; Liang, W.H.; Ou, C.Q.; He, J.X.; Liu, L.; Shan, H.; Lei, C.L.; Hui, D.S.C.; et al. Clinical Characteristics of Coronavirus Disease 2019 in China. N. Engl. J. Med. 2020, 382, 1708-1720. [CrossRef] [PubMed]

3. Driggin, E.; Madhavan, M.V.; Bikdeli, B.; Chuich, T.; Laracy, J.; Bondi-Zoccai, G.; Brown, T.S.; Nigoghossian, C.; Zidar, D.A.; Haythe, J.; et al. Cardiovascular Considerations for Patients, Health Care Workers, and Health Systems During the Coronavirus Disease 2019 (COVID-19) Pandemic. J. Am. Coll. Cardiol. 2020, 75, 2352-2371. [CrossRef]

4. Wu, Z.; McGoogan, J.M. Characteristics of and Important Lessons From the Coronavirus Disease 2019 (COVID-19) Outbreak in China: Summary of a Report of 72314 Cases From the Chinese Center for Disease Control and Prevention. JAMA 2020, 323, 1239-1242. [CrossRef]

5. Ruan, Q.; Yang, K.; Wang, W.; Jiang, L.; Song, J. Clinical predictors of mortality due to COVID-19 based on an analysis of data of 150 patients from Wuhan, China. Intensive Care Med. 2020, 46, 846-848. [CrossRef]

6. Huang, C.; Wang, Y.; Li, X.; Ren, L.; Zhao, J.; Hu, Y.; Zhang, L.; Fan, G.; Xu, J.; Gu, X.; et al. Clinical features of patients infected with 2019 novel coronavirus in Wuhan, China. Lancet 2020, 395, 497-506. [CrossRef]

7. Zhou, F.; Yu, T.; Du, R.; Fan, G.; Liu, Y.; Liu, Z.; Xiang, J.; Wang, Y.; Song, B.; Gu, X.; et al. Clinical course and risk factors for mortality of adult inpatients with COVID-19 in Wuhan, China: A retrospective cohort study. Lancet 2020, 395, 1054-1062. [CrossRef]

8. Wang, D.; Hu, B.; Hu, C.; Zhu, F.; Liu, X.; Zhang, J.; Wang, B.; Xiang, H.; Cheng, Z.; Xiong, Y.; et al. Clinical Characteristics of 138 Hospitalized Patients With 2019 Novel Coronavirus-Infected Pneumonia in Wuhan, China. JAMA 2020, 323, 1061-1069. [CrossRef] 
9. Yang, X.; Yu, Y.; Xu, J.; Shu, H.; Xia, J.; Liu, H.; Wu, Y.; Zhang, L.; Yu, Z.; Fang, M.; et al. Clinical course and outcomes of critically ill patients with SARS-CoV-2 pneumonia in Wuhan, China: A single-centered, retrospective, observational study. Lancet Respir. Med. 2020, 8, 475-481. [CrossRef]

10. Li, B.; Yang, J.; Zhao, F.; Zhi, L.; Wang, X.; Liu, L.; Bi, Z.; Zhao, Y. Prevalence and impact of cardiovascular metabolic diseases on COVID-19 in China. Clin. Res. Cardiol. 2020, 109, 531-538. [CrossRef] [PubMed]

11. Murthy, S.; Gomersall, C.D.; Fowler, R.A. Care for Critically Ill Patients with COVID-19. JAMA 2020, 323, 1499-1500. [CrossRef] [PubMed]

12. Hoffmann, M.; Kleine-Weber, H.; Schroeder, S.; Kruger, N.; Herrler, T.; Erichsen, S.; Schiergens, T.S.; Herrler, G.; Wu, N.H.; Nitsche, A.; et al. SARS-CoV-2 Cell Entry Depends on ACE2 and TMPRSS2 and Is Blocked by a Clinically Proven Protease Inhibitor. Cell 2020, 181, 271.e8-280.e8. [CrossRef] [PubMed]

13. Shi, Y.; Wang, Y.; Shao, C.; Huang, J.; Gan, J.; Huang, X.; Bucci, E.; Piacentini, M.; Ippolito, G.; Melino, G. COVID-19 infection: The perspectives on immune responses. Cell Death Differ. 2020,27,1451-1454. [CrossRef] [PubMed]

14. Wu, C.H.; Mohammadmoradi, S.; Chen, J.Z.; Sawada, H.; Daugherty, A.; Lu, H.S. Renin-Angiotensin System and Cardiovascular Functions. Arterioscler. Thromb. Vasc. Biol. 2018, 38, e108-e116. [CrossRef]

15. Vincent, M.J.; Bergeron, E.; Benjannet, S.; Erickson, B.R.; Rollin, P.E.; Ksiazek, T.G.; Seidah, N.G.; Nichol, S.T. Chloroquine is a potent inhibitor of SARS coronavirus infection and spread. Virol. J. 2005, 2, 69. [CrossRef]

16. Keyaerts, E.; Vijgen, L.; Maes, P.; Neyts, J.; Van Ranst, M. In vitro inhibition of severe acute respiratory syndrome coronavirus by chloroquine. Biochem. Biophys. Res. Commun. 2004, 323, 264-268. [CrossRef]

17. Biot, C.; Daher, W.; Chavain, N.; Fandeur, T.; Khalife, J.; Dive, D.; De Clercq, E. Design and synthesis of hydroxyferroquine derivatives with antimalarial and antiviral activities. J. Med. Chem. 2006, 49, 2845-2849. [CrossRef]

18. Yao, X.; Ye, F.; Zhang, M.; Cui, C.; Huang, B.; Niu, P.; Liu, X.; Zhao, L.; Dong, E.; Song, C.; et al. In Vitro Antiviral Activity and Projection of Optimized Dosing Design of Hydroxychloroquine for the Treatment of Severe Acute Respiratory Syndrome Coronavirus 2 (SARS-CoV-2). Clin. Infect. Dis. 2020. [CrossRef]

19. Wang, M.; Cao, R.; Zhang, L.; Yang, X.; Liu, J.; Xu, M.; Shi, Z.; Hu, Z.; Zhong, W.; Xiao, G. Remdesivir and chloroquine effectively inhibit the recently emerged novel coronavirus (2019-nCoV) in vitro. Cell Res. 2020, 30, 269-271. [CrossRef]

20. Cortegiani, A.; Ingoglia, G.; Ippolito, M.; Giarratano, A.; Einav, S. A systematic review on the efficacy and safety of chloroquine for the treatment of COVID-19. J. Crit. Care 2020, 57, 279-283. [CrossRef]

21. Chen, J.; Liu, D.; Liu, L.; Liu, P.; Xu, Q.; Xia, L.; Ling, Y.; Huang, D.; Song, S.; Zhang, D.; et al. [A pilot study of hydroxychloroquine in treatment of patients with moderate COVID-19]. Zhejiang da xue xue bao. Yi xue ban = Journal of Zhejiang University. Med. Sci. 2020, 49, 215-219.

22. Gautret, P.; Lagier, J.C.; Parola, P.; Hoang, V.T.; Meddeb, L.; Mailhe, M.; Doudier, B.; Courjon, J.; Giordanengo, V.; Vieira, V.E.; et al. Hydroxychloroquine and azithromycin as a treatment of COVID-19: Results of an open-label non-randomized clinical trial. Int. J. Antimicrob. Agents 2020. [CrossRef] [PubMed]

23. Molina, J.M.; Delaugerre, C.; Le Goff, J.; Mela-Lima, B.; Ponscarme, D.; Goldwirt, L.; de Castro, N. No evidence of rapid antiviral clearance or clinical benefit with the combination of hydroxychloroquine and azithromycin in patients with severe COVID-19 infection. Med. Mal. Infect. 2020, 50, 30085-30088. [CrossRef] [PubMed]

24. Gao, J.; Tian, Z.; Yang, X. Breakthrough: Chloroquine phosphate has shown apparent efficacy in treatment of COVID-19 associated pneumonia in clinical studies. Biosci. Trends 2020, 14, 72-73. [CrossRef]

25. Gautret, P.; Lagier, J.C.; Parola, P.; Hoang, V.T.; Meddeb, L.; Sevestre, J.; Mailhe, M.; Doudier, B.; Aubry, C.; Amrane, S.; et al. Clinical and microbiological effect of a combination of hydroxychloroquine and azithromycin in 80 COVID-19 patients with at least a six-day follow up: A pilot observational study. Travel Med. Infect. Dis. 2020, 34, 101663. [CrossRef]

26. Coronaviridae Study Group of the International Committee on Taxonomy of Viruses. The species Severe acute respiratory syndrome-related coronavirus: Classifying 2019-nCoV and naming it SARS-CoV-2. Nat. Microbiol. 2020, 5, 536-544. [CrossRef]

27. Wu, C.; Liu, Y.; Yang, Y.; Zhang, P.; Zhong, W.; Wang, Y.; Wang, Q.; Xu, Y.; Li, M.; Li, X.; et al. Analysis of therapeutic targets for SARS-CoV-2 and discovery of potential drugs by computational methods. Acta Pharm. Sin. B 2020, 10, 766-788. [CrossRef] 
28. Xu, X.; Chen, P.; Wang, J.; Feng, J.; Zhou, H.; Li, X.; Zhong, W.; Hao, P. Evolution of the novel coronavirus from the ongoing Wuhan outbreak and modeling of its spike protein for risk of human transmission. Sci. China Life Sci. 2020, 63, 457-460. [CrossRef] [PubMed]

29. Chan, J.F.; Kok, K.H.; Zhu, Z.; Chu, H.; To, K.K.; Yuan, S.; Yuen, K.Y. Genomic characterization of the 2019 novel human-pathogenic coronavirus isolated from a patient with atypical pneumonia after visiting Wuhan. Emerg. Microbes Infect. 2020, 9, 221-236. [CrossRef] [PubMed]

30. Li, W.; Moore, M.J.; Vasilieva, N.; Sui, J.; Wong, S.K.; Berne, M.A.; Somasundaran, M.; Sullivan, J.L.; Luzuriaga, K.; Greenough, T.C.; et al. Angiotensin-converting enzyme 2 is a functional receptor for the SARS coronavirus. Nature 2003, 426, 450-454. [CrossRef] [PubMed]

31. Hamming, I.; Timens, W.; Bulthuis, M.L.; Lely, A.T.; Navis, G.; van Goor, H. Tissue distribution of ACE2 protein, the functional receptor for SARS coronavirus. A first step in understanding SARS pathogenesis. J. Pathol. 2004, 203, 631-637. [CrossRef] [PubMed]

32. Yousif, M.H.; Dhaunsi, G.S.; Makki, B.M.; Qabazard, B.A.; Akhtar, S.; Benter, I.F. Characterization of Angiotensin-(1-7) effects on the cardiovascular system in an experimental model of type-1 diabetes. Pharmacol. Res. 2012, 66, 269-275. [CrossRef] [PubMed]

33. Jiang, F.; Yang, J.; Zhang, Y.; Dong, M.; Wang, S.; Zhang, Q.; Liu, F.F.; Zhang, K.; Zhang, C. Angiotensin-converting enzyme 2 and angiotensin 1-7: Novel therapeutic targets. Nat. Rev. Cardiol. 2014, 11, 413-426. [CrossRef] [PubMed]

34. Zheng, Y.Y.; Ma, Y.T.; Zhang, J.Y.; Xie, X. COVID-19 and the cardiovascular system. Nat. Rev. Cardiol. 2020, 17, 259-260. [CrossRef]

35. Fang, Z.; Yi, F.; Wu, K.; Lai, K.; Sun, X.; Zhong, N.; Liu, Z. Clinical Characteristics of 2019 Coronavirus Pneumonia (COVID-19): An Updated Systematic Review. medRxiv 2020. Available online: https://www. medrxiv.org/content/10.1101/2020.03.07.20032573v2 (accessed on 30 June 2020).

36. Lu, Y.; Wang, P.; Zhou, T.; Lu, J.; Spatz, E.S.; Nasir, K.; Jiang, L.; Krumholz, H.M. Comparison of Prevalence, Awareness, Treatment, and Control of Cardiovascular Risk Factors in China and the United States. J. Am. Heart Assoc. 2018, 7, e007462. [CrossRef]

37. Wu, C.; Chen, X.; Cai, Y.; Xia, J.; Zhou, X.; Xu, S.; Huang, H.; Zhang, L.; Zhou, X.; Du, C.; et al. Risk Factors Associated with Acute Respiratory Distress Syndrome and Death in Patients With Coronavirus Disease 2019 Pneumonia in Wuhan, China. JAMA Intern. Med. 2020. [CrossRef]

38. Chen, N.; Zhou, M.; Dong, X.; Qu, J.; Gong, F.; Han, Y.; Qiu, Y.; Wang, J.; Liu, Y.; Wei, Y.; et al. Epidemiological and clinical characteristics of 99 cases of 2019 novel coronavirus pneumonia in Wuhan, China: A descriptive study. Lancet 2020, 395, 507-513. [CrossRef]

39. Liu, K.; Fang, Y.Y.; Deng, Y.; Liu, W.; Wang, M.F.; Ma, J.P.; Xiao, W.; Wang, Y.N.; Zhong, M.H.; Li, C.H.; et al. Clinical characteristics of novel coronavirus cases in tertiary hospitals in Hubei Province. Chin. Med J. 2020, 133, 1025-1031. [CrossRef]

40. Porcheddu, R.; Serra, C.; Kelvin, D.; Kelvin, N.; Rubino, S. Similarity in Case Fatality Rates (CFR) of COVID-19/SARS-COV-2 in Italy and China. J. Infect. Dev. Ctries. 2020, 14, 125-128. [CrossRef]

41. Liu, Y.; Yang, Y.; Zhang, C.; Huang, F.; Wang, F.; Yuan, J.; Wang, Z.; Li, J.; Li, J.; Feng, C.; et al. Clinical and biochemical indexes from 2019-nCoV infected patients linked to viral loads and lung injury. Sci. China Life Sci. 2020, 63, 364-374. [CrossRef]

42. Lippi, G.; Lavie, C.J.; Sanchis-Gomar, F. Cardiac troponin I in patients with coronavirus disease 2019 (COVID-19): Evidence from a meta-analysis. Prog. Cardiovasc. Dis. 2020. [CrossRef]

43. Chen, C.F.; Chien, C.H.; Yang, Y.P.; Chou, S.J.; Wang, M.L.; Huo, T.I.; Lin, C.C. Role of Dipeptidyl Peptidase 4 Inhibitors in Diabetic Patients with Coronavirus-19 Infection. J. Chin. Med Assoc. 2020. [CrossRef]

44. Chen, L.; Li, X.; Chen, M.; Feng, Y.; Xiong, C. The ACE2 expression in human heart indicates new potential mechanism of heart injury among patients infected with SARS-CoV-2. Cardiovasc. Res. 2020, 116, 1097-1100. [CrossRef] [PubMed]

45. Inciardi, R.M.; Lupi, L.; Zaccone, G.; Italia, L.; Raffo, M.; Tomasoni, D.; Cani, D.S.; Cerini, M.; Farina, D.; Gavazzi, E.; et al. Cardiac Involvement in a Patient with Coronavirus Disease 2019 (COVID-19). JAMA Cardiol. 2020. [CrossRef] [PubMed]

46. Musher, D.M.; Abers, M.S.; Corrales-Medina, V.F. Acute Infection and Myocardial Infarction. N. Engl. J. Med. 2019, 380, 171-176. [CrossRef] [PubMed] 
47. Zeng, J.; Huang, J.; Pan, L. How to balance acute myocardial infarction and COVID-19: The protocols from Sichuan Provincial People's Hospital. Intensive Care Med. 2020. [CrossRef]

48. Cole, J.E.; Park, I.; Ahern, D.J.; Kassiteridi, C.; Danso Abeam, D.; Goddard, M.E.; Green, P.; Maffia, P.; Monaco, C. Immune cell census in murine atherosclerosis: Cytometry by time of flight illuminates vascular myeloid cell diversity. Cardiovasc. Res. 2018, 114, 1360-1371. [CrossRef]

49. Tang, N.; Li, D.; Wang, X.; Sun, Z. Abnormal coagulation parameters are associated with poor prognosis in patients with novel coronavirus pneumonia. J. Thromb. Haemost. 2020, 18, 844-847. [CrossRef]

50. Danzi, G.B.; Loffi, M.; Galeazzi, G.; Gherbesi, E. Acute pulmonary embolism and COVID-19 pneumonia: A random association? Eur. Heart J. 2020, 41, 1858. [CrossRef]

51. Mehta, P.; McAuley, D.F.; Brown, M.; Sanchez, E.; Tattersall, R.S.; Manson, J.J.; Hlh Across Speciality Collaboration, U.K. COVID-19: Consider cytokine storm syndromes and immunosuppression. Lancet 2020, 395, 1033-1034. [CrossRef]

52. Ziegler, L.; Gajulapuri, A.; Frumento, P.; Bonomi, A.; Wallen, H.; de Faire, U.; Rose-John, S.; Gigante, B. Interleukin 6 trans-signalling and risk of future cardiovascular events. Cardiovasc. Res. 2019, 115, $213-221$. [CrossRef] [PubMed]

53. Ferrante, G.; Condorelli, G. Interleukin-6 trans-signalling and risk of future cardiovascular events: A new avenue for atheroprotection? Cardiovasc. Res. 2019, 115, 8-9. [CrossRef] [PubMed]

54. Chappell, M.C. Biochemical evaluation of the renin-angiotensin system: The good, bad, and absolute? American journal of physiology. Heart Circ. Physiol. 2016, 310, H137-H152. [CrossRef] [PubMed]

55. Dostal, D.E.; Baker, K.M. The cardiac renin-angiotensin system: Conceptual, or a regulator of cardiac function? Circ. Res. 1999, 85, 643-650. [CrossRef] [PubMed]

56. Donoghue, M.; Hsieh, F.; Baronas, E.; Godbout, K.; Gosselin, M.; Stagliano, N.; Donovan, M.; Woolf, B.; Robison, K.; Jeyaseelan, R.; et al. A novel angiotensin-converting enzyme-related carboxypeptidase (ACE2) converts angiotensin I to angiotensin 1-9. Circ. Res. 2000, 87, E1-E9. [CrossRef]

57. Chappell, M.C. Emerging evidence for a functional angiotensin-converting enzyme 2-angiotensin-(1-7)-MAS receptor axis: More than regulation of blood pressure? Hypertension 2007, 50, 596-599. [CrossRef]

58. Xia, H.; Lazartigues, E. Angiotensin-converting enzyme 2: Central regulator for cardiovascular function. Curr. Hypertens. Rep. 2010, 12, 170-175. [CrossRef]

59. Sodhi, C.P.; Wohlford-Lenane, C.; Yamaguchi, Y.; Prindle, T.; Fulton, W.B.; Wang, S.; McCray, P.B., Jr.; Chappell, M.; Hackam, D.J.; Jia, H. Attenuation of pulmonary ACE2 activity impairs inactivation of des-Arg(9) bradykinin/BKB1R axis and facilitates LPS-induced neutrophil infiltration. Am. J. Physiol. Lung Cell. Mol. Physiol. 2018, 314, L17-L31. [CrossRef]

60. Kuba, K.; Imai, Y.; Rao, S.; Gao, H.; Guo, F.; Guan, B.; Huan, Y.; Yang, P.; Zhang, Y.; Deng, W.; et al. A crucial role of angiotensin converting enzyme 2 (ACE2) in SARS coronavirus-induced lung injury. Nat. Med. 2005, 11, 875-879. [CrossRef]

61. Letko, M.; Marzi, A.; Munster, V. Functional assessment of cell entry and receptor usage for SARS-CoV-2 and other lineage B betacoronaviruses. Nat. Microbiol. 2020, 5, 562-569. [CrossRef]

62. Zou, Z.; Yan, Y.; Shu, Y.; Gao, R.; Sun, Y.; Li, X.; Ju, X.; Liang, Z.; Liu, Q.; Zhao, Y.; et al. Angiotensin-converting enzyme 2 protects from lethal avian influenza A H5N1 infections. Nat. Commun. 2014, 5, 3594. [CrossRef] [PubMed]

63. Yang, P.; Gu, H.; Zhao, Z.; Wang, W.; Cao, B.; Lai, C.; Yang, X.; Zhang, L.; Duan, Y.; Zhang, S.; et al. Angiotensin-converting enzyme 2 (ACE2) mediates influenza H7N9 virus-induced acute lung injury. Sci. Rep. 2014, 4, 7027. [CrossRef] [PubMed]

64. Liu, X.; Yang, N.; Tang, J.; Liu, S.; Luo, D.; Duan, Q.; Wang, X. Downregulation of angiotensin-converting enzyme 2 by the neuraminidase protein of influenza A (H1N1) virus. Virus Res. 2014, 185, 64-71. [CrossRef] [PubMed]

65. Williams, V.R.; Scholey, J.W. Angiotensin-converting enzyme 2 and renal disease. Curr. Opin. Nephrol. Hypertens. 2018, 27, 35-41. [CrossRef]

66. Assiri, A.; McGeer, A.; Perl, T.M.; Price, C.S.; Al Rabeeah, A.A.; Cummings, D.A.; Alabdullatif, Z.N.; Assad, M.; Almulhim, A.; Makhdoom, H.; et al. Hospital outbreak of Middle East respiratory syndrome coronavirus. N. Engl. J. Med. 2013, 369, 407-416. [CrossRef] 
67. Woo, P.C.; Lau, S.K.; Lam, C.S.; Lau, C.C.; Tsang, A.K.; Lau, J.H.; Bai, R.; Teng, J.L.; Tsang, C.C.; Wang, M.; et al. Discovery of seven novel Mammalian and avian coronaviruses in the genus deltacoronavirus supports bat coronaviruses as the gene source of alphacoronavirus and betacoronavirus and avian coronaviruses as the gene source of gammacoronavirus and deltacoronavirus. J. Virol. 2012, 86, 3995-4008. [CrossRef]

68. Shang, J.; Ye, G.; Shi, K.; Wan, Y.; Luo, C.; Aihara, H.; Geng, Q.; Auerbach, A.; Li, F. Structural basis of receptor recognition by SARS-CoV-2. Nature 2020, 581, 221-224. [CrossRef]

69. Wrapp, D.; Wang, N.; Corbett, K.S.; Goldsmith, J.A.; Hsieh, C.L.; Abiona, O.; Graham, B.S.; McLellan, J.S. Cryo-EM structure of the 2019-nCoV spike in the prefusion conformation. Science 2020, 367, 1260-1263. [CrossRef]

70. Yang, J.; Zheng, Y.; Gou, X.; Pu, K.; Chen, Z.; Guo, Q.; Ji, R.; Wang, H.; Wang, Y.; Zhou, Y. Prevalence of comorbidities and its effects in coronavirus disease 2019 patients: A systematic review and meta-analysis. Int. J. Infect. Dis. 2020, 94, 91-95. [CrossRef]

71. Patel, V.B.; Zhong, J.C.; Grant, M.B.; Oudit, G.Y. Role of the ACE2/Angiotensin 1-7 Axis of the Renin-Angiotensin System in Heart Failure. Circ. Res. 2016, 118, 1313-1326. [CrossRef]

72. Santos, R.A.S.; Oudit, G.Y.; Verano-Braga, T.; Canta, G.; Steckelings, U.M.; Bader, M. The renin-angiotensin system: Going beyond the classical paradigms. Am. J. Physiol. Heart Circ. Physiol. 2019, 316, H958-H970. [CrossRef]

73. Simoes, E.S.A.C.; Teixeira, M.M. ACE inhibition, ACE2 and angiotensin-(1-7) axis in kidney and cardiac inflammation and fibrosis. Pharmacol. Res. 2016, 107, 154-162. [CrossRef]

74. Zhang, C.; Zhao, Y.X.; Zhang, Y.H.; Zhu, L.; Deng, B.P.; Zhou, Z.L.; Li, S.Y.; Lu, X.T.; Song, L.L.; Lei, X.M.; et al. Angiotensin-converting enzyme 2 attenuates atherosclerotic lesions by targeting vascular cells. Proc. Natl. Acad. Sci. USA 2010, 107, 15886-15891. [CrossRef]

75. Imai, Y.; Kuba, K.; Rao, S.; Huan, Y.; Guo, F.; Guan, B.; Yang, P.; Sarao, R.; Wada, T.; Leong-Poi, H.; et al. Angiotensin-converting enzyme 2 protects from severe acute lung failure. Nature 2005, 436, 112-116. [CrossRef]

76. Parajuli, N.; Ramprasath, T.; Patel, V.B.; Wang, W.; Putko, B.; Mori, J.; Oudit, G.Y. Targeting angiotensin-converting enzyme 2 as a new therapeutic target for cardiovascular diseases. Can. J. Physiol. Pharmacol. 2014, 92, 558-565. [CrossRef]

77. Khanna, A.; English, S.W.; Wang, X.S.; Ham, K.; Tumlin, J.; Szerlip, H.; Busse, L.W.; Altaweel, L.; Albertson, T.E.; Mackey, C.; et al. Angiotensin II for the Treatment of Vasodilatory Shock. N. Engl. J. Med. 2017, 377, 419-430. [CrossRef]

78. Monteil, V.; Kwon, H.; Prado, P.; Hagelkruys, A.; Wimmer, R.A.; Stahl, M.; Leopoldi, A.; Garreta, E.; Hurtado Del Pozo, C.; Prosper, F.; et al. Inhibition of SARS-CoV-2 Infections in Engineered Human Tissues Using Clinical-Grade Soluble Human ACE2. Cell 2020, 181, 905-913.e7. [CrossRef]

79. Han, D.P.; Penn-Nicholson, A.; Cho, M.W. Identification of critical determinants on ACE2 for SARS-CoV entry and development of a potent entry inhibitor. Virology 2006, 350, 15-25. [CrossRef]

80. Iwata-Yoshikawa, N.; Okamura, T.; Shimizu, Y.; Hasegawa, H.; Takeda, M.; Nagata, N. TMPRSS2 Contributes to Virus Spread and Immunopathology in the Airways of Murine Models after Coronavirus Infection. J. Virol. 2019, 93. [CrossRef]

81. Zhou, Y.; Vedantham, P.; Lu, K.; Agudelo, J.; Carrion, R., Jr.; Nunneley, J.W.; Barnard, D.; Pohlmann, S.; McKerrow, J.H.; Renslo, A.R.; et al. Protease inhibitors targeting coronavirus and filovirus entry. Antivir. Res. 2015, 116, 76-84. [CrossRef]

82. Uhlen, M.; Zhang, C.; Lee, S.; Sjostedt, E.; Fagerberg, L.; Bidkhori, G.; Benfeitas, R.; Arif, M.; Liu, Z.; Edfors, F.; et al. A pathology atlas of the human cancer transcriptome. Science 2017, 357. [CrossRef] [PubMed]

83. Bertram, S.; Heurich, A.; Lavender, H.; Gierer, S.; Danisch, S.; Perin, P.; Lucas, J.M.; Nelson, P.S.; Pohlmann, S.; Soilleux, E.J. Influenza and SARS-coronavirus activating proteases TMPRSS2 and HAT are expressed at multiple sites in human respiratory and gastrointestinal tracts. PLoS ONE 2012, 7, e35876. [CrossRef] [PubMed]

84. Zhou, Y.; Hou, Y.; Shen, J.; Huang, Y.; Martin, W.; Cheng, F. Network-based drug repurposing for novel coronavirus 2019-nCoV/SARS-CoV-2. Cell Discov. 2020, 6, 14. [CrossRef] [PubMed]

85. Liu, J.; Cao, R.; Xu, M.; Wang, X.; Zhang, H.; Hu, H.; Li, Y.; Hu, Z.; Zhong, W.; Wang, M. Hydroxychloroquine, a less toxic derivative of chloroquine, is effective in inhibiting SARS-CoV-2 infection in vitro. Cell Discov. 2020, 6, 16. [CrossRef] 
86. Coatney, G.R. Pitfalls in a discovery: The chronicle of chloroquine. Am. J. Trop. Med. Hyg. 1963, 12, 121-128. [CrossRef]

87. Raoult, D.; Drancourt, M.; Vestris, G. Bactericidal effect of doxycycline associated with lysosomotropic agents on Coxiella burnetii in P388D1 cells. Antimicrob. Agents Chemother. 1990, 34, 1512-1514. [CrossRef]

88. Boulos, A.; Rolain, J.M.; Raoult, D. Antibiotic susceptibility of Tropheryma whipplei in MRC5 cells. Antimicrob. Agents Chemother. 2004, 48, 747-752. [CrossRef]

89. Rolain, J.M.; Colson, P.; Raoult, D. Recycling of chloroquine and its hydroxyl analogue to face bacterial, fungal and viral infections in the 21st century. Int. J. Antimicrob. Agents 2007, 30, 297-308. [CrossRef]

90. Savarino, A.; Boelaert, J.R.; Cassone, A.; Majori, G.; Cauda, R. Effects of chloroquine on viral infections: An old drug against today's diseases? The Lancet. Infect. Dis. 2003, 3, 722-727. [CrossRef]

91. Boelaert, J.R.; Piette, J.; Sperber, K. The potential place of chloroquine in the treatment of HIV-1-infected patients. J. Clin. Virol. 2001, 20, 137-140. [CrossRef]

92. Lee, S.J.; Silverman, E.; Bargman, J.M. The role of antimalarial agents in the treatment of SLE and lupus nephritis. Nat. Rev. Nephrol. 2011, 7, 718-729. [CrossRef] [PubMed]

93. Blau, D.M.; Holmes, K.V. Human coronavirus HCoV-229E enters susceptible cells via the endocytic pathway. Adv. Exp. Med. Biol. 2001, 494, 193-198. [CrossRef] [PubMed]

94. Kono, M.; Tatsumi, K.; Imai, A.M.; Saito, K.; Kuriyama, T.; Shirasawa, H. Inhibition of human coronavirus 229E infection in human epithelial lung cells (L132) by chloroquine: Involvement of p38 MAPK and ERK. Antivir. Res. 2008, 77, 150-152. [CrossRef]

95. Keyaerts, E.; Li, S.; Vijgen, L.; Rysman, E.; Verbeeck, J.; Van Ranst, M.; Maes, P. Antiviral activity of chloroquine against human coronavirus OC43 infection in newborn mice. Antimicrob. Agents Chemother. 2009, 53, 3416-3421. [CrossRef] [PubMed]

96. Winzeler, E.A. Malaria research in the post-genomic era. Nature 2008, 455, 751-756. [CrossRef] [PubMed]

97. Ohkuma, S.; Poole, B. Cytoplasmic vacuolation of mouse peritoneal macrophages and the uptake into lysosomes of weakly basic substances. J. Cell Biol. 1981, 90, 656-664. [CrossRef]

98. Popert, A.J. Chloroquine: A review. Rheumatol. Rehabil. 1976, 15, 235-238. [CrossRef]

99. Lim, H.S.; Im, J.S.; Cho, J.Y.; Bae, K.S.; Klein, T.A.; Yeom, J.S.; Kim, T.S.; Choi, J.S.; Jang, I.J.; Park, J.W. Pharmacokinetics of hydroxychloroquine and its clinical implications in chemoprophylaxis against malaria caused by Plasmodium vivax. Antimicrob. Agents Chemother. 2009, 53, 1468-1475. [CrossRef]

100. Andreani, J.; Le Bideau, M.; Duflot, I.; Jardot, P.; Rolland, C.; Boxberger, M.; Wurtz, N.; Rolain, J.M.; Colson, P.; La Scola, B.; et al. In vitro testing of combined hydroxychloroquine and azithromycin on SARS-CoV-2 shows synergistic effect. Microb. Pathog. 2020, 145, 104228. [CrossRef]

101. Chen, Z.; Hu, J.; Zhang, Z.; Jiang, S.; Han, S.; Yan, D.; Zhuang, R.; Hu, B.; Zhang, Z. Efficacy of hydroxychloroquine in patients with COVID-19: Results of a randomized clinical trial. MedRxiv 2020. Available online: https://www.medrxiv.org/content/10.1101/2020.03.22.20040758v3 (accessed on 30 June 2020).

102. Mahevas, M.; Tran, V.-T.; Roumier, M.; Chabrol, A.; Paule, R.; Guillaud, C.; Gallien, S.; Lepeule, R.; Szwebel, T.-A.; Lescure, X. No evidence of clinical efficacy of hydroxychloroquine in patients hospitalized for COVID-19 infection with oxygen requirement: Results of a study using routinely collected data to emulate a target trial. MedRxiv 2020. Available online: https://www.medrxiv.org/content/10.1101/2020.04.10.20060699v1 (accessed on 30 June 2020).

103. Tang, W.; Cao, Z.; Han, M.; Wang, Z.; Chen, J.; Sun, W.; Wu, Y.; Xiao, W.; Liu, S.; Chen, E.; et al. Hydroxychloroquine in patients with mainly mild to moderate coronavirus disease 2019: Open label, randomised controlled trial. BMJ 2020,369, m1849. [CrossRef]

104. Million, M.; Lagier, J.C.; Gautret, P.; Colson, P.; Fournier, P.E.; Amrane, S.; Hocquart, M.; Mailhe, M.; Esteves-Vieira, V.; Doudier, B.; et al. Early treatment of COVID-19 patients with hydroxychloroquine and azithromycin: A retrospective analysis of 1061 cases in Marseille, France. Travel Med. Infect. Dis. 2020, 35, 101738. [CrossRef] [PubMed]

105. Magagnoli, J.; Narendran, S.; Pereira, F.; Cummings, T.; Hardin, J.W.; Sutton, S.S.; Ambati, J. Outcomes of hydroxychloroquine usage in United States veterans hospitalized with Covid-19. MedRxiv 2020. Available online: https://www.medrxiv.org/content/10.1101/2020.04.16.20065920v2 (accessed on 30 June 2020).

106. Mathies, D.; Rauschning, D.; Wagner, U.; Mueller, F.; Maibaum, M.; Binnemann, C.; Waldeck, S.; Thinnes, K.; Braun, M.; Schmidbauer, W.; et al. A Case of SARS-CoV-2-pneumonia with successful antiviral therapy in a 77-year-old male with heart transplant. Am. J. Transplant. 2020. [CrossRef] [PubMed] 
107. Lane, J.C.E.; Weaver, J.; Kostka, K.; Duarte-Salles, T.; Abrahao, M.T.F.; Alghoul, H.; Alser, O.; Alshammari, T.M.; Biedermann, P.; Burn, E. Safety of hydroxychloroquine, alone and in combination with azithromycin, in light of rapid wide-spread use for COVID-19: A multinational, network cohort and self-controlled case series study. MedRxiv 2020. Available online: https://www.medrxiv.org/content/10.1101/2020.04.08.20054551v2 (accessed on 30 June 2020).

108. Kwiek, J.J.; Haystead, T.A.; Rudolph, J. Kinetic mechanism of quinone oxidoreductase 2 and its inhibition by the antimalarial quinolines. Biochemistry 2004, 43, 4538-4547. [CrossRef] [PubMed]

109. Varki, A. Sialic acids as ligands in recognition phenomena. FASEB J. 1997, 11, 248-255. [CrossRef]

110. Olofsson, S.; Kumlin, U.; Dimock, K.; Arnberg, N. Avian influenza and sialic acid receptors: More than meets the eye? Lancet Infect. Dis. 2005, 5, 184-188. [CrossRef]

111. Byrd, T.F.; Horwitz, M.A. Chloroquine inhibits the intracellular multiplication of Legionella pneumophila by limiting the availability of iron. A potential new mechanism for the therapeutic effect of chloroquine against intracellular pathogens. J. Clin. Investig. 1991, 88, 351-357. [CrossRef]

112. Legssyer, R.; Josse, C.; Piette, J.; Ward, R.J.; Crichton, R.R. Changes in function of iron-loaded alveolar macrophages after in vivo administration of desferrioxamine and/or chloroquine. J. Inorg. Biochem. 2003, 94, 36-42. [CrossRef]

113. Gay, B.; Bernard, E.; Solignat, M.; Chazal, N.; Devaux, C.; Briant, L. pH-dependent entry of chikungunya virus into Aedes albopictus cells. Infect. Genet. Evol. 2012, 12, 1275-1281. [CrossRef]

114. Tricou, V.; Minh, N.N.; Van, T.P.; Lee, S.J.; Farrar, J.; Wills, B.; Tran, H.T.; Simmons, C.P. A randomized controlled trial of chloroquine for the treatment of dengue in Vietnamese adults. PLoS Negl. Trop. Dis. 2010, 4, e785. [CrossRef]

115. Khan, M.; Santhosh, S.R.; Tiwari, M.; Lakshmana Rao, P.V.; Parida, M. Assessment of in vitro prophylactic and therapeutic efficacy of chloroquine against Chikungunya virus in vero cells. J. Med. Virol. 2010, 82, 817-824. [CrossRef]

116. Yang, Z.Y.; Huang, Y.; Ganesh, L.; Leung, K.; Kong, W.P.; Schwartz, O.; Subbarao, K.; Nabel, G.J. pH-dependent entry of severe acute respiratory syndrome coronavirus is mediated by the spike glycoprotein and enhanced by dendritic cell transfer through DC-SIGN. J. Virol. 2004, 78, 5642-5650. [CrossRef] [PubMed]

117. Wang, H.; Yang, P.; Liu, K.; Guo, F.; Zhang, Y.; Zhang, G.; Jiang, C. SARS coronavirus entry into host cells through a novel clathrin- and caveolae-independent endocytic pathway. Cell Res. 2008, 18, $290-301$. [CrossRef] [PubMed]

118. Casanova, L.; Rutala, W.A.; Weber, D.J.; Sobsey, M.D. Coronavirus survival on healthcare personal protective equipment. Infect. Control Hosp. Epidemiol. 2010, 31, 560-561. [CrossRef] [PubMed]

119. Bishop, N.E. Examination of potential inhibitors of hepatitis A virus uncoating. Intervirology 1998, 41, $261-271$. [CrossRef] [PubMed]

120. Savarino, A.; Gennero, L.; Sperber, K.; Boelaert, J.R. The anti-HIV-1 activity of chloroquine. J. Clin. Virol. 2001, 20, 131-135. [CrossRef]

121. Fonseca, B.A.; Pincus, S.; Shope, R.E.; Paoletti, E.; Mason, P.W. Recombinant vaccinia viruses co-expressing dengue-1 glycoproteins prM and E induce neutralizing antibodies in mice. Vaccine 1994, 12, $279-285$. [CrossRef]

122. Harley, C.A.; Dasgupta, A.; Wilson, D.W. Characterization of herpes simplex virus-containing organelles by subcellular fractionation: Role for organelle acidification in assembly of infectious particles. J. Virol. 2001, 75, 1236-1251. [CrossRef]

123. Klumperman, J.; Locker, J.K.; Meijer, A.; Horzinek, M.C.; Geuze, H.J.; Rottier, P.J. Coronavirus M proteins accumulate in the Golgi complex beyond the site of virion budding. J. Virol. 1994, 68, 6523-6534. [CrossRef]

124. Perrier, A.; Bonnin, A.; Desmarets, L.; Danneels, A.; Goffard, A.; Rouille, Y.; Dubuisson, J.; Belouzard, S. The C-terminal domain of the MERS coronavirus M protein contains a trans-Golgi network localization signal. J. Biol. Chem. 2019, 294, 14406-14421. [CrossRef]

125. Jang, C.H.; Choi, J.H.; Byun, M.S.; Jue, D.M. Chloroquine inhibits production of TNF-alpha, IL-1beta and IL-6 from lipopolysaccharide-stimulated human monocytes/macrophages by different modes. Rheumatology 2006, 45, 703-710. [CrossRef]

126. Seitz, M.; Valbracht, J.; Quach, J.; Lotz, M. Gold sodium thiomalate and chloroquine inhibit cytokine production in monocytic THP-1 cells through distinct transcriptional and posttranslational mechanisms. J. Clin. Immunol. 2003, 23, 477-484. [CrossRef] 
127. Zhu, X.; Ertel, W.; Ayala, A.; Morrison, M.H.; Perrin, M.M.; Chaudry, I.H. Chloroquine inhibits macrophage tumour necrosis factor-alpha mRNA transcription. Immunology 1993, 80, 122-126. [PubMed]

128. Farias, K.J.; Machado, P.R.; de Almeida Junior, R.F.; de Aquino, A.A.; da Fonseca, B.A. Chloroquine interferes with dengue-2 virus replication in U937 cells. Microbiol. Immunol. 2014, 58, 318-326. [CrossRef] [PubMed]

129. Jeong, J.Y.; Jue, D.M. Chloroquine inhibits processing of tumor necrosis factor in lipopolysaccharide-stimulated RAW 264.7 macrophages. J. Immunol. 1997, 158, 4901-4907.

130. Bondeson, J.; Sundler, R. Antimalarial drugs inhibit phospholipase A2 activation and induction of interleukin 1beta and tumor necrosis factor alpha in macrophages: Implications for their mode of action in rheumatoid arthritis. Gen. Pharmacol. 1998, 30, 357-366. [CrossRef]

131. van den Borne, B.E.; Dijkmans, B.A.; de Rooij, H.H.; le Cessie, S.; Verweij, C.L. Chloroquine and hydroxychloroquine equally affect tumor necrosis factor-alpha, interleukin 6, and interferon-gamma production by peripheral blood mononuclear cells. J. Rheumatol. 1997, 24, 55-60.

132. Karres, I.; Kremer, J.P.; Dietl, I.; Steckholzer, U.; Jochum, M.; Ertel, W. Chloroquine inhibits proinflammatory cytokine release into human whole blood. Am. J. Physiol. 1998, 274, R1058-R1064. [CrossRef]

133. Nooteboom, A.; Hendriks, T.; Otteholler, I.; van der Linden, C.J. Permeability characteristics of human endothelial monolayers seeded on different extracellular matrix proteins. Mediat. Inflamm. 2000, 9, $235-241$. [CrossRef]

134. Jeong, J.Y.; Choi, J.W.; Jeon, K.I.; Jue, D.M. Chloroquine decreases cell-surface expression of tumour necrosis factor receptors in human histiocytic U-937 cells. Immunology 2002, 105, 83-91. [CrossRef]

135. Wolfe, F.; Caplan, L.; Michaud, K. Treatment for rheumatoid arthritis and the risk of hospitalization for pneumonia: Associations with prednisone, disease-modifying antirheumatic drugs, and anti-tumor necrosis factor therapy. Arthritis Rheum. 2006, 54, 628-634. [CrossRef]

136. Bernatsky, S.; Hudson, M.; Suissa, S. Anti-rheumatic drug use and risk of serious infections in rheumatoid arthritis. Rheumatology 2007, 46, 1157-1160. [CrossRef]

137. Smitten, A.L.; Choi, H.K.; Hochberg, M.C.; Suissa, S.; Simon, T.A.; Testa, M.A.; Chan, K.A. The risk of hospitalized infection in patients with rheumatoid arthritis. J. Rheumatol. 2008, 35, 387-393.

138. Rokni, M.; Ghasemi, V.; Tavakoli, Z. Immune responses and pathogenesis of SARS-CoV-2 during an outbreak in Iran: Comparison with SARS and MERS. Rev. Med Virol. 2020, 30, e2107. [CrossRef]

139. Sheahan, T.; Morrison, T.E.; Funkhouser, W.; Uematsu, S.; Akira, S.; Baric, R.S.; Heise, M.T. MyD88 is required for protection from lethal infection with a mouse-adapted SARS-CoV. PLoS Pathog. 2008, 4, e1000240. [CrossRef]

140. An, J.; Woodward, J.J.; Sasaki, T.; Minie, M.; Elkon, K.B. Cutting edge: Antimalarial drugs inhibit IFN-beta production through blockade of cyclic GMP-AMP synthase-DNA interaction. J. Immunol. 2015, 194, 4089-4093. [CrossRef]

141. Maringer, K.; Fernandez-Sesma, A. Message in a bottle: Lessons learned from antagonism of STING signalling during RNA virus infection. Cytokine Growth Factor Rev. 2014, 25, 669-679. [CrossRef]

142. Lokugamage, K.G.; Hage, A.; Schindewolf, C.; Rajsbaum, R.; Menachery, V.D. SARS-CoV-2 sensitive to type I interferon pretreatment. BioRxiv 2020. Available online: https://www.biorxiv.org/content/10.1101/2020.03.07. $982264 \mathrm{v} 3$ (accessed on 30 June 2020).

143. Austin Taylor, M.; Bennett, M.; Kumar, V.; Schatzle, J.D. Functional defects of NK cells treated with chloroquine mimic the lytic defects observed in perforin-deficient mice. J. Immunol. 2000, 165, 5048-5053. [CrossRef]

144. Yang, J.; Yang, X.; Yang, J.; Li, M. Hydroxychloroquine Inhibits the Differentiation of Th17 Cells in Systemic Lupus Erythematosus. J. Rheumatol. 2018, 45, 818-826. [CrossRef]

145. Oh, S.; Shin, J.H.; Jang, E.J.; Won, H.Y.; Kim, H.K.; Jeong, M.G.; Kim, K.S.; Hwang, E.S. Anti-inflammatory activity of chloroquine and amodiaquine through p21-mediated suppression of T cell proliferation and Th1 cell differentiation. Biochem. Biophys. Res. Commun. 2016, 474, 345-350. [CrossRef]

146. Schrezenmeier, E.; Dorner, T. Mechanisms of action of hydroxychloroquine and chloroquine: Implications for rheumatology. Nat. Rev. Rheumatol. 2020, 16, 155-166. [CrossRef]

147. Mocholi, E.; Dowling, S.D.; Botbol, Y.; Gruber, R.C.; Ray, A.K.; Vastert, S.; Shafit-Zagardo, B.; Coffer, P.J.; Macian, F. Autophagy Is a Tolerance-Avoidance Mechanism that Modulates TCR-Mediated Signaling and Cell Metabolism to Prevent Induction of T Cell Anergy. Cell Rep. 2018, 24, 1136-1150. [CrossRef] 
148. Briant, L.; Robert-Hebmann, V.; Acquaviva, C.; Pelchen-Matthews, A.; Marsh, M.; Devaux, C. The protein tyrosine kinase p56lck is required for triggering NF-kappaB activation upon interaction of human immunodeficiency virus type 1 envelope glycoprotein gp120 with cell surface CD4. J. Virol. 1998, 72, 6207-6214. [CrossRef]

149. Kreutz, R.; Algharably, E.A.E.; Azizi, M.; Dobrowolski, P.; Guzik, T.; Januszewicz, A.; Persu, A.; Prejbisz, A.; Riemer, T.G.; Wang, J.G.; et al. Hypertension, the renin-angiotensin system, and the risk of lower respiratory tract infections and lung injury: Implications for COVID-19. Cardiovasc. Res. 2020. [CrossRef]

150. Gutierrez, F.; Masia, M.; Mirete, C.; Soldan, B.; Rodriguez, J.C.; Padilla, S.; Hernandez, I.; Royo, G.; Martin-Hidalgo, A. The influence of age and gender on the population-based incidence of community-acquired pneumonia caused by different microbial pathogens. J. Infect. 2006, 53, 166-174. [CrossRef]

151. Soto, M.; Bang, S.I.; McCombs, J.; Rodgers, K.E. Renin Angiotensin system-modifying therapies are associated with improved pulmonary health. Clin. Diabetes Endocrinol. 2017, 3, 6. [CrossRef]

152. Henry, C.; Zaizafoun, M.; Stock, E.; Ghamande, S.; Arroliga, A.C.; White, H.D. Impact of angiotensin-converting enzyme inhibitors and statins on viral pneumonia. Proceedings 2018, 31, 419-423. [CrossRef]

153. Sanchez-Aguilar, M.; Ibarra-Lara, L.; Del Valle-Mondragon, L.; Rubio-Ruiz, M.E.; Aguilar-Navarro, A.G.; Zamorano-Carrillo, A.; Ramirez-Ortega, M.D.C.; Pastelin-Hernandez, G.; Sanchez-Mendoza, A. Rosiglitazone, a Ligand to PPARgamma, Improves Blood Pressure and Vascular Function through Renin-Angiotensin System Regulation. PPAR Res. 2019, 2019, 1371758. [CrossRef]

154. Beaney, T.; Burrell, L.M.; Castillo, R.R.; Charchar, F.J.; Cro, S.; Damasceno, A.; Kruger, R.; Nilsson, P.M.; Prabhakaran, D.; Ramirez, A.J.; et al. May Measurement Month 2018: A pragmatic global screening campaign to raise awareness of blood pressure by the International Society of Hypertension. Eur. Heart J. 2019, 40, 2006-2017. [CrossRef]

155. Meulenbelt, J.; van Bree, L.; Dormans, J.A.; Boink, A.B.; Sangster, B. Biochemical and histological alterations in rats after acute nitrogen dioxide intoxication. Hum. Exp. Toxicol. 1992, 11, 189-200. [CrossRef]

156. Patel, J.M.; Sekharam, K.M.; Block, E.R. Oxidant injury increases cell surface receptor binding of angiotensin II to pulmonary artery endothelial cells. J. Biochem. Toxicol. 1990, 5, 253-258. [CrossRef] [PubMed]

157. Oakes, J.M.; Fuchs, R.M.; Gardner, J.D.; Lazartigues, E.; Yue, X. Nicotine and the renin-angiotensin system. American journal of physiology. Regul. Integr. Comp. Physiol. 2018, 315, R895-R906. [CrossRef] [PubMed]

158. Lippi, G.; Henry, B.M. Active smoking is not associated with severity of coronavirus disease 2019 (COVID-19). Eur. J. Intern. Med. 2020, 75, 107-108. [CrossRef] [PubMed]

159. Yang, B.Y.; Guo, Y.; Markevych, I.; Qian, Z.M.; Bloom, M.S.; Heinrich, J.; Dharmage, S.C.; Rolling, C.A.; Jordan, S.S.; Komppula, M.; et al. Association of Long-term Exposure to Ambient Air Pollutants With Risk Factors for Cardiovascular Disease in China. JAMA Netw. Open 2019, 2, e190318. [CrossRef] [PubMed]

160. Cui, Y.; Zhang, Z.F.; Froines, J.; Zhao, J.; Wang, H.; Yu, S.Z.; Detels, R. Air pollution and case fatality of SARS in the People's Republic of China: An ecologic study. Environ. Health Glob. Access Sci. Source 2003, 2, 15. [CrossRef]

161. Zhang, Q.; Cong, M.; Wang, N.; Li, X.; Zhang, H.; Zhang, K.; Jin, M.; Wu, N.; Qiu, C.; Li, J. Association of angiotensin-converting enzyme 2 gene polymorphism and enzymatic activity with essential hypertension in different gender: A case-control study. Medicine 2018, 97, e12917. [CrossRef]

162. Lu, N.; Yang, Y.; Wang, Y.; Liu, Y.; Fu, G.; Chen, D.; Dai, H.; Fan, X.; Hui, R.; Zheng, Y. ACE2 gene polymorphism and essential hypertension: An updated meta-analysis involving 11,051 subjects. Mol. Biol. Rep. 2012, 39, 6581-6589. [CrossRef]

163. Huang, J.; Chen, S.; Lu, X.; Zhao, Q.; Rao, D.C.; Jaquish, C.E.; Hixson, J.E.; Chen, J.; Wang, L.; Cao, J.; et al. Polymorphisms of ACE2 are associated with blood pressure response to cold pressor test: The GenSalt study. Am. J. Hypertens. 2012, 25, 937-942. [CrossRef]

164. Pinheiro, D.S.; Santos, R.S.; Jardim, P.; Silva, E.G.; Reis, A.A.S.; Pedrino, G.R.; Ulhoa, C.J. The combination of ACE I/D and ACE2 G8790A polymorphisms revels susceptibility to hypertension: A genetic association study in Brazilian patients. PLoS ONE 2019, 14, e0221248. [CrossRef]

165. Schouten, L.R.; van Kaam, A.H.; Kohse, F.; Veltkamp, F.; Bos, L.D.; de Beer, F.M.; van Hooijdonk, R.T.; Horn, J.; Straat, M.; Witteveen, E.; et al. Age-dependent differences in pulmonary host responses in ARDS: A prospective observational cohort study. Ann. Intensive Care 2019, 9, 55. [CrossRef] 
166. Grasselli, G.; Zangrillo, A.; Zanella, A.; Antonelli, M.; Cabrini, L.; Castelli, A.; Cereda, D.; Coluccello, A.; Foti, G.; Fumagalli, R.; et al. Baseline Characteristics and Outcomes of 1591 Patients Infected With SARS-CoV-2 Admitted to ICUs of the Lombardy Region, Italy. JAMA 2020, 323, 1574-1581. [CrossRef]

167. Touret, F.; de Lamballerie, X. Of chloroquine and COVID-19. Antivir. Res. 2020, 177, 104762. [CrossRef] [PubMed]

168. Calain, P. The Ebola clinical trials: A precedent for research ethics in disasters. J. Med. Ethics 2018, 44, 3-8. [CrossRef] [PubMed]

169. Frisk-Holmberg, M.; Bergqvist, Y.; Englund, U. Chloroquine intoxication. Br. J. Clin. Pharmacol. 1983, 15, 502-503. [CrossRef]

170. Chatre, C.; Roubille, F.; Vernhet, H.; Jorgensen, C.; Pers, Y.M. Cardiac Complications Attributed to Chloroquine and Hydroxychloroquine: A Systematic Review of the Literature. Drug Saf. 2018, 41, 919-931. [CrossRef] [PubMed]

171. Laing, R.; Waning, B.; Gray, A.; Ford, N.; t Hoen, E. 25 years of the WHO essential medicines lists: Progress and challenges. Lancet 2003, 361, 1723-1729. [CrossRef]

172. Crumb, W.J., Jr.; Vicente, J.; Johannesen, L.; Strauss, D.G. An evaluation of 30 clinical drugs against the comprehensive in vitro proarrhythmia assay (CiPA) proposed ion channel panel. J. Pharmacol. Toxicol. Methods 2016, 81, 251-262. [CrossRef] [PubMed]

173. Tonnesmann, E.; Kandolf, R.; Lewalter, T. Chloroquine cardiomyopathy-A review of the literature. Immunopharmacol. Immunotoxicol. 2013, 35, 434-442. [CrossRef]

174. Mzayek, F.; Deng, H.; Mather, F.J.; Wasilevich, E.C.; Liu, H.; Hadi, C.M.; Chansolme, D.H.; Murphy, H.A.; Melek, B.H.; Tenaglia, A.N.; et al. Randomized dose-ranging controlled trial of AQ-13, a candidate antimalarial, and chloroquine in healthy volunteers. PLoS Clin. Trials 2007, 2, e6. [CrossRef] [PubMed]

175. Chorin, E.; Wadhwani, L.; Magnani, S.; Dai, M.; Shulman, E.; Nadeau-Routhier, C.; Knotts, R.; Bar-Cohen, R.; Kogan, E.; Barbhaiya, C. QT Interval Prolongation and Torsade De Pointes in Patients with COVID-19 treated with Hydroxychloroquine/Azithromycin. Heart Rhythm. 2020. [CrossRef] [PubMed]

176. Cao, B.; Wang, Y.; Wen, D.; Liu, W.; Wang, J.; Fan, G.; Ruan, L.; Song, B.; Cai, Y.; Wei, M.; et al. A Trial of Lopinavir-Ritonavir in Adults Hospitalized with Severe Covid-19. N. Engl. J. Med. 2020, 382, 1787-1799. [CrossRef] [PubMed]

177. Hofmann, H.; Geier, M.; Marzi, A.; Krumbiegel, M.; Peipp, M.; Fey, G.H.; Gramberg, T.; Pohlmann, S. Susceptibility to SARS coronavirus $\mathrm{S}$ protein-driven infection correlates with expression of angiotensin converting enzyme 2 and infection can be blocked by soluble receptor. Biochem. Biophys. Res. Commun. 2004, 319, 1216-1221. [CrossRef] [PubMed]

178. Ferrario, C.M.; Jessup, J.; Chappell, M.C.; Averill, D.B.; Brosnihan, K.B.; Tallant, E.A.; Diz, D.I.; Gallagher, P.E. Effect of angiotensin-converting enzyme inhibition and angiotensin II receptor blockers on cardiac angiotensin-converting enzyme 2. Circulation 2005, 111, 2605-2610. [CrossRef] [PubMed]

179. Asan Medical Center. Comparison of Lopinavir/Ritonavir or Hydroxychloroquine in Patients with Mild Coronavirus Disease (COVID-19). Available online: https://ClinicalTrials.gov/show/NCT04307693 (accessed on 30 June 2020).

180. Shanghai Public Health Clinical Center. Efficacy and Safety of Hydroxychloroquine for Treatment of COVID-19. Available online: https://ClinicalTrials.gov/show/NCT04261517 (accessed on 30 June 2020).

181. University of Minnesota; McGill University Health Centre/Research Institute of the McGill University Health Centre; University of Manitoba; University of Alberta. Post-exposure Prophylaxis Preemptive Therapy for SARS-Coronavirus-2. Available online: https:/ClinicalTrials.gov/show/NCT04308668 (accessed on 30 June 2020).

182. Corrales-Medina, V.F.; Alvarez, K.N.; Weissfeld, L.A.; Angus, D.C.; Chirinos, J.A.; Chang, C.C.; Newman, A.; Loehr, L.; Folsom, A.R.; Elkind, M.S.; et al. Association between hospitalization for pneumonia and subsequent risk of cardiovascular disease. JAMA 2015, 313, 264-274. [CrossRef]

183. Wu, Q.; Zhou, L.; Sun, X.; Yan, Z.; Hu, C.; Wu, J.; Xu, L.; Li, X.; Liu, H.; Yin, P.; et al. Altered Lipid Metabolism in Recovered SARS Patients Twelve Years after Infection. Sci. Rep. 2017, 7, 9110. [CrossRef] [PubMed]

(C) 2020 by the authors. Licensee MDPI, Basel, Switzerland. This article is an open access article distributed under the terms and conditions of the Creative Commons Attribution (CC BY) license (http://creativecommons.org/licenses/by/4.0/). 